\title{
Incorporating Wind Generation in Cap and Trade Programs
}

Technical Report NREL/TP-500-40006 July 2006

Joel Bluestein

Energy and Environmental Analysis, Inc.

Elizabeth Salerno

American Wind Energy Association

Lori Bird and Laura Vimmerstedt National Renewable Energy Laboratory 


\section{Incorporating Wind Generation in Cap and Trade Programs}

Technical Report NREL/TP-500-4006 July 2006

Joel Bluestein

Energy and Environmental Analysis, Inc.

Elizabeth Salerno

American Wind Energy Association

Lori Bird and Laura Vimmerstedt

National Renewable Energy Laboratory

Prepared under Task No. WER6 6006

National Renewable Energy Laboratory

1617 Cole Boulevard, Golden, Colorado 80401-3393

303-275-3000 • www.nrel.gov

Operated for the U.S. Department of Energy

Office of Energy Efficiency and Renewable Energy

by Midwest Research Institute • Battelle

Contract No. DE-AC36-99-G010337

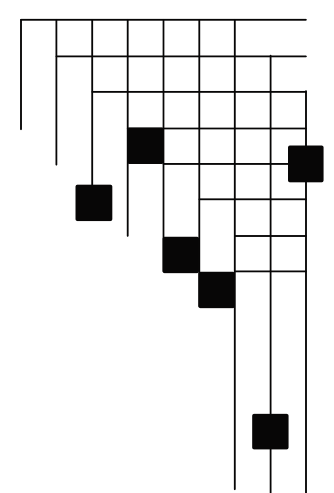




\section{NOTICE}

This report was prepared as an account of work sponsored by an agency of the United States government. Neither the United States government nor any agency thereof, nor any of their employees, makes any warranty, express or implied, or assumes any legal liability or responsibility for the accuracy, completeness, or usefulness of any information, apparatus, product, or process disclosed, or represents that its use would not infringe privately owned rights. Reference herein to any specific commercial product, process, or service by trade name, trademark, manufacturer, or otherwise does not necessarily constitute or imply its endorsement, recommendation, or favoring by the United States government or any agency thereof. The views and opinions of authors expressed herein do not necessarily state or reflect those of the United States government or any agency thereof.

Available electronically at http://www.osti.gov/bridge

Available for a processing fee to U.S. Department of Energy and its contractors, in paper, from:

U.S. Department of Energy

Office of Scientific and Technical Information

P.O. Box 62

Oak Ridge, TN 37831-0062

phone: 865.576.8401

fax: 865.576 .5728

email: mailto:reports@adonis.osti.gov

Available for sale to the public, in paper, from:

U.S. Department of Commerce

National Technical Information Service

5285 Port Royal Road

Springfield, VA 22161

phone: 800.553 .6847

fax: 703.605.6900

email: orders@ntis.fedworld.gov

online ordering: http://www.ntis.gov/ordering.htm 


\section{Table of Contents}

FIGURE

LIST OF TABLES ii

ACKNOWLEDGEMENTS 1

EXECUTIVE SUMMARY 2

1. INTRODUCTION 4

2. FUNDAMENTALS OF CAP AND TRADE PROGRAM DESIGN __ 6

2.1 OVERVIEW OF CAP AND TRADE PROGRAMS

2.2 ALLOWANCE DisTRIBUTION

2.2.1 Method of Allowance Distribution

2.2.2 Frequency and Basis for Distribution

3. IMPLICATIONS: POLICYMAKER AND WIND GENERATOR PERSPECTIVES

3.1 STATE AND EPA RATIONALES FOR INCLUDING RENEWABLE GENERATION IN CAP AND TRADE PROGRAMS _ 11

3.2. How CAP AND TRADE Programs CAN BeNEFIT Wind GeNERATORS

3.2.1 Selling Allowances into the Market for Emission Allowances

3.2.2 Retiring or Bundling Allowances to Participate in Voluntary Retail or Compliance Renewable Energy

Markets

3.2.3 Retiring Allowances to Create Creditable Emission Reductions

4. HOW CAN WIND GENERATION BE INCLUDED IN CAP AND TRADE PROGRAMS?

4.1 RENEWABLE ENERGY SET-ASIDES

4.1.1 Design of a Renewable Energy Set-Aside

Definition of Eligible Technologies and Projects

Size of Set-Aside and Addressing Oversubscription

Distribution Procedure

Administrative Burden

4.1.2 Advantages of a Renewable Energy Set-Aside

4.1.3 Disadvantages of a Renewable Energy Set-Aside

4.1.4 Experience with EE/RE Set-Asides

Experience with State Set-Aside Programs 22

4.2 DiReCt OutPut-Based Allocation to ReNEWABle ENERGY ___ 24

4.2.1 Design of Output-Based Allocation to Wind Generators — 24

Definition of Eligible Technologies and Projects__ 25

New Source Set-Aside __ 25

4.2.2 Advantages of Direct Output-Based Allocation to Wind Generators___ 25

4.2.3 Disadvantages of Direct Output-Based Allocation to Wind Generators ___ 26

5. INCORPORATING RENEWABLE ENERGY INTO THE CLEAN AIR INTERSTATE RULE __ 28

5.1 THE EPA MOdel RULE __ 29

5.2 RENEWABLE ENERGY SET-ASIDE___ 30

5.3 Direct ALLOCATION TO RENEWABLE ENERGY

5.3.1 Full Output-Based Allocation System __ 34

5.3.2 New Source Set-Aside 34

5.4 DECREASE LAG TIME FOR ALLOCATIONS___ 35

6. SUMMARY AND CONCLUSIONS _ 37

APPENDIX A. RESOURCES _ 39 
APPENDIX B. RESOLUTION SUPPORTING EMISSIONS ALLOCATIONS FOR NEW CLEAN ENERGY

SOURCES

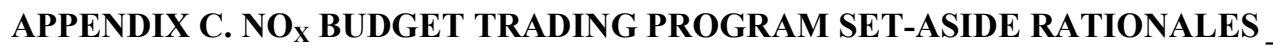
42

GLOSSARY OF ABBREVIATIONS AND ACRONYMS 43

REFERENCES 44

\section{Figure}

Figure 1. States affected by the Clean Air Interstate Rule (U.S. EPA) [21] 28

\section{List of Tables}

Table 1: Allowance Distribution Design Features 7

Table 2. Summary of SIP Call Set-Aside Parameters 


\section{Acknowledgements}

The authors gratefully acknowledge the contributions of others to this report. This work was funded by the U.S. Department of Energy (DOE) Office of Energy Efficiency and Renewable Energy (EERE) under the Wind Powering America program. The authors wish to thank Phil Dougherty of the U.S. DOE for his support. We appreciate the guidance of Lawrence Flowers, Wind Powering America lead at the National Renewable Energy Laboratory (NREL). The American Wind Energy Association (AWEA) provided wind industry perspectives, leadership, and support.

We thank contacts who offered insights on their experiences with wind energy projects under cap and trade programs, including:

Julia Blankenship, AMP Ohio

Tom Carnahan, Wind Capital Group

Dale Osborn, Berkshire Wind Farm

Kevin Rackstraw, Clipper Wind

Tom Rawls, THR Associates LLC

We wish to acknowledge the following reviewers for their insightful comments:

Paul Denholm and Doug Arent, NREL

Ed Holt, Ed Holt \& Associates, Inc.

William Lamkin, State of Massachusetts

Robert McCarron, State of Minnesota

Karen Palmer, Resources for the Future

Kevin Rackstraw and Rob Gramlich, AWEA

Tom Rawls, THR Associates LLC

We are grateful to Ruth Baranowski, NREL, for editorial support and Gail Mosey, NREL, for research support.

Although we appreciate these contributions, the authors retain responsibility for any remaining errors in this report. 


\section{Executive Summary}

Cap and trade programs are increasingly being used to reduce emissions from electricity generation in the United States. Cap and trade programs primarily target emitting generators, but programs have also included renewable generators, such as wind generators.

States cite several reasons why they have considered the policy option of including renewable generators in cap and trade programs: to provide an incentive for lower-emitting generation, to achieve emissions reductions in non-capped pollutants, and to gain local economic benefits associated with renewable energy projects. The U.S. Environmental Protection Agency also notes these rationales for considering this policy alternative, and the National Association of Regulatory Commissioners (NARUC) passed a resolution supporting the inclusion of renewable energy in cap and trade programs. This report explores why states consider this policy option, what participation could mean for wind generators, and how wind generation can most effectively be included in state, federal, and regional cap and trade programs.

Including wind generators in a cap and trade program could serve as a tangible incentive, through several mechanisms. Wind generators could receive an allocation of emission allowances and then sell them to emitting generators. They could receive allowances and retire them on behalf of customers when they participate in voluntary retail renewable energy markets. Similarly, wind generators could simply retire emissions allowances to make creditable emission reduction claims, with possible secondary financial benefit. If allowances were auctioned instead of being allocated for free, policymakers could use auction proceeds toward policy goals and could consider incentives for wind generators among their other options.

While other methods are possible, states are now using or considering two primary methods to include renewable generators in cap and trade programs that target generation: renewable energy set-asides and direct output-based allocation to renewable generators.

A set-aside establishes a specific amount of allowances for renewable generators, offering certainty for existing generators about the number of allowances allocated to them, but imposing uncertainty (and reduced value) on renewable generators about future allowance allocations if the set-aside becomes too small to accommodate all new renewable energy generators in the longterm. For regulators and affected generators, the administrative costs of a set-aside may also be higher than direct output-based allocation.

Under a direct output-based approach, allowances are allocated to all generators, including renewable energy generators, from the main allowance pool based on generation output. This makes all generators part of the main allocation process, reducing administrative costs relative to a set-aside and increasing certainty for renewable generators about future allowance availability. The primary drawbacks to this approach, relative to a set-aside, are that it has not been used in emission trading programs to date, and it could reduce allocation to conventional generators as renewable generation shares increase. 
This report includes sample regulatory language to allocate allowances to wind generators under the Clean Air Interstate Rule (CAIR) using either of these methods. These regulatory approaches will also be relevant if future trading programs, especially for $\mathrm{CO}_{2}$, present similar opportunities.

To date, wind generator participation in cap and trade programs has proven to be highly sensitive to transaction costs and regulatory issues. Programs to include renewable generation in cap and trade will benefit from ongoing evaluation of "best practices" to improve their design and implementation. 


\section{Introduction}

Cap and trade programs ${ }^{\mathrm{a}}$ are one of the leading policy choices for reducing electricity-sector emissions in the United States ${ }^{b}$ [1]. The U.S. Environmental Protection Agency (EPA) notes that the strengths of this market-based approach include simplicity, excellent compliance record, and cost-effectiveness [2]. A number of cap and trade programs have been or are currently being implemented or proposed at the state, regional, and national level in the United States.

- The Clean Air Act Amendments of 1990 established the first national cap and trade program in the form of the Title IV sulfur dioxide $\left(\mathrm{SO}_{2}\right)$ cap and trade program for electric utility generators to address acid rain [3].

- In 1999, the 12 states of the Northeast Ozone Transport Region ${ }^{\mathrm{c}}$ implemented a $\mathrm{NO}_{\mathrm{x}}$ Budget Trading program to reduce regional transport of nitrogen oxides $\left(\mathrm{NO}_{\mathrm{x}}\right)$, a precursor to ground-level ozone (smog). The program used a regional, summertime cap and trade program to reduce $\mathrm{NO}_{\mathrm{x}}$ emissions from large stationary sources. [4]

- In 2003, the $\mathrm{NO}_{\mathrm{x}}$ Budget Trading Program was expanded to 22 northeastern states ${ }^{\mathrm{d}}$ [4] under the $\mathrm{NO}_{\mathrm{x}}$ SIP Call promulgated by the EPA in 1998 [5].

- In 2005, the U.S. EPA promulgated the Clean Air Interstate Rule (CAIR), expanding the scope of the $\mathrm{NO}_{\mathrm{x}}$ Budget Trading Program to 28 eastern U.S. states ${ }^{\mathrm{e}}$ and establishing both summertime and year-round $\mathrm{NO}_{\mathrm{x}}$ cap programs. The EPA also promulgated the Clean Air Mercury Rule (CAMR), which allows states to participate in a national trading program for mercury emissions from coal-fired power plants [6].

- In December 2005, seven Northeastern states endorsed a regional cap and trade program to reduce carbon dioxide $\left(\mathrm{CO}_{2}\right)$ emissions from power plants. If implemented, this would become the first binding regional cap and trade program on greenhouse gases in the United States [7].

- Several bills have been proposed or discussed in the U.S. Senate to establish national cap and trade programs for $\mathrm{SO}_{2}, \mathrm{NO}_{\mathrm{x}}$, mercury, and $\mathrm{CO}_{2}[8]$.

\footnotetext{
${ }^{\text {a }}$ A cap and trade program for emissions control establishes a total emissions cap for an identifiable group of sources of a specific, measurable pollutant; establishes a market for allowances that represent emissions of that pollutant; and allows allowance trading among the sources. Though related, offset programs are sufficiently different that they are not discussed in this report.

${ }^{\mathrm{b}}$ Other emissions reduction approaches include performance standards for emissions rates for existing and new power plants, plant-specific emissions caps, requirements to use specific control technologies, and pollution taxes. Analysis of these alternatives is beyond the scope of this report.

${ }^{\mathrm{c}}$ Connecticut, Delaware, Maine, Maryland, Massachusetts, New Hampshire, New Jersey, New York, Pennsylvania, Rhode Island, northern Virginia, and Washington, D.C. (D.C. is treated as a state for air quality regulation.)

${ }^{\mathrm{d}}$ Alabama, Connecticut, Delaware, Illinois, Indiana, Kentucky, Maryland, Massachusetts, New Jersey, New York, North Carolina, Ohio, Pennsylvania, Rhode Island, South Carolina, Tennessee, Virginia, Washington, D.C., West Virginia, and parts of Georgia (Phase 2), Michigan, and Missouri (Phase 2)

${ }^{\mathrm{e}}$ Includes NOx Budget Trading Program states except Rhode Island, and also adds Arkansas, Florida, Iowa, Minnesota, Mississippi, Texas, and Wisconsin
} 
Cap and trade programs designed to reduce emissions from electricity generation primarily target emitting generators. Wind and other types of renewable electricity generation generally have lower air emissions than fossil-fuel generation, leading to public policy interest in using renewable generation to reduce emissions in the electricity sector. Some states have shown interest in policies to include renewable generators in cap and trade programs. They view this policy alternative as an incentive for lower-emitting generation that will achieve emissions reductions in non-capped pollutants and offer the local economic benefits associated with renewable energy projects.

This report explores why states consider policies to include wind in cap and trade programs, why there has been little participation among wind and other renewable energy generators in cap and trade programs to date, the mechanisms by which wind generators could benefit from participation, and how wind generation can most effectively be included in these programs. The report covers methods for including wind generators in emission reduction programs that are in use today or under active consideration in current state regulatory decisions, including:

- Allocation of allowance set-asides to renewable energy

- Output-based allocation of allowances to wind generators. ${ }^{\mathrm{f}}$

Because this report is sponsored by the Wind Powering America ${ }^{\mathrm{g}}$ program, it focuses on wind generation; however, the practices and regulatory principles discussed in this report apply generally to non-emitting renewable generators and in some cases, to energy efficiency measures. And while the report provides specific regulatory options for allocating allowances to renewable generators under the CAIR, the overall findings of this report are generally applicable to other cap and trade programs as well.

Effective inclusion of wind generation in cap and trade programs has implications beyond the CAIR and $\mathrm{NO}_{\mathrm{x}}$ Budget Trading Programs. Regulations on national electric-sector $\mathrm{CO}_{2}$ and greenhouse gas emissions would most likely use cap and trade programs, similar to programs already being implemented at the state and regional levels.

Chapter 2 of this report provides a general background on emissions trading, primarily for readers not already familiar with or who would like a review of cap and trade programs. Chapter 3 explores reasons why including renewable energy in cap and trade programs is considered and examines the different approaches by which wind generators could benefit from programs. Chapter 4 discusses the specific approaches to including wind generators in cap and trade programs. Chapter 5 illustrates the inclusion of wind generators in state regulation in response to the CAIR, including regulatory language that can be used for that purpose. Chapter 6 offers a summary and conclusions.

\footnotetext{
${ }^{\mathrm{f}}$ Specific design details of California's load-based program are not determined at this time, so detailed analysis of that approach is beyond the scope of this report. See California Public Utilities Commission. Decision 06-02-032 February 16, 2006. Order Instituting Rulemaking to Promote Policy and Program Coordination and Integration in Electric Utility Resource Planning. Rulemaking 04-04-003 (Filed April 1, 2004) http://www.cpuc.ca.gov/PUBLISHED/FINAL DECISION/53720.htm\#P89 1988. Accessed June 14, 2006.

g The U.S. Department of Energy's Wind Powering America program seeks to increase the use of wind energy in the United States (see http://www.windpoweringamerica.gov).
} 


\section{Fundamentals of Cap and Trade Program Design}

\subsection{Overview of Cap and Trade Programs}

Emissions regulation options include market-based approaches, such as pollution taxes and cap and trade programs, and non-market approaches, such as pollution standards for emissions rates for existing and new power plants, plant-specific emissions caps, and requirements to use specific control technologies. Cap and trade programs are a market-based emission regulation approach, and as such are fundamentally different from non-market regulations, such as plant-specific emissions standards [9]. Under a cap and trade program, an overall emission tonnage cap is set for an affected sector or set of plants. ${ }^{\mathrm{h}}$ For example, the Title IV acid rain $\mathrm{SO}_{2}$ trading program sets a cap of approximately 9 million tons of $\mathrm{SO}_{2}$ emissions per year for U.S. power plants.

Allowances are created that represent a temporary right to emit one unit (e.g., 1 ton) of the allowable cap. The allowances are distributed to the affected plants. The primary compliance requirement is that each plant must hold allowances equal to its actual emissions at the end of each compliance period. However, there is no fixed emission cap or limit on individual plants, and each plant's emissions are not limited to the allowances that it receives. It can purchase additional allowances from another plant or it can sell allowances if it has a surplus.

A cap and trade program has several benefits. The emission cap leads to greater certainty in the overall level of emissions than other approaches because the total tons of emissions are held to a specific limit regardless of plant operation or growth in the sector. The trading program also can help reduce the cost of compliance relative to non-market approaches because it allows reductions to be made at plants where they cost the least, rather than requiring specific reductions from each plant. In theory, trading encourages plants with lower cost of control to make more reductions while plants with higher control cost make fewer. Through trading, all plants have the option of compliance at essentially the same cost per ton, reducing the overall cost of compliance to consumers and the regulatory impact on plants with higher control costs [10].

The trading program also monetizes emissions and control investments. Each ton of pollutant emitted has a specific cost because it requires the retirement of an allowance that has a market value. Plant operators seek to recover this cost in competitive electricity markets, creating an ongoing market incentive to reduce emissions to make each plant more competitive.

While the cap fixes the total emissions from the sector, the cap and trade program does not impose a fixed emission limit at the plant level. ${ }^{\mathrm{i}}$ Each plant can emit more or less each year as long as it can acquire the required allowances. If a plant faces emissions control options that are more expensive than the market price of allowances, then the least-cost option for that plant may be to forego emission controls, emit more than its allowance allocation, and purchase allowances. If allowances are more expensive, it may pay to install capital-intensive control technology and

\footnotetext{
${ }^{\mathrm{h}}$ Markets for tradable emissions commodities, such as offsets, also have been established. These markets do not establish an emissions cap. Because this approach differs substantially from cap and trade, it is beyond the scope of this report.

${ }^{\mathrm{i}}$ Other regulations, such as state permits and New Source Review, do impose plant-specific limits.
} 
possibly have allowances to sell. The total cost of compliance for the individual plant under a cap and trade program is the cost of allowances retired to cover emissions plus the capital and operating costs of any control measures that may be installed.

\subsection{Allowance Distribution}

Many of the effects of a cap and trade program are not inherent to the basic program but instead are a function of how the allowances are distributed. Allowances must be distributed to affected entities in some way. The distribution design does not affect the overall level of emissions (the cap) and may not affect the dispatch of specific generating assets. However, it can affect the profitability of individual units, amount of generation from each unit, total program cost, and the future choice of generating technologies. Because allowance distribution can affect the competitiveness and profits of individual companies, it can be one of the most contentious and politically difficult aspects of cap and trade program design.

The key design features of allowance distribution can be thought of as three design decisions that result in numerous possible policy designs. Table 1 shows a simplified summary of the major combinations of policy design features, with each arrow representing possible combinations.

Table 1: Allowance Distribution Design Features

\begin{tabular}{|l|c|l|l|l|l|l|}
\hline Design Decision & \multicolumn{5}{|c|}{ Options } \\
\hline $\begin{array}{l}\text { Distribution } \\
\text { Method }\end{array}$ & \multicolumn{3}{|c|}{ Free Allocation } & \multicolumn{2}{c|}{ Auction } \\
\hline $\begin{array}{l}\text { Frequency of } \\
\text { Distribution }\end{array}$ & \multicolumn{2}{|c|}{$\begin{array}{l}\text { One time } \\
\text { (grandfathering) }\end{array}$} & $\begin{array}{l}\text { Updating } \\
\text { (reallocation) }\end{array}$ & $\begin{array}{l}\text { One time } \\
\text { (grandfathering) }\end{array}$ & $\begin{array}{l}\text { Updating } \\
\text { (reallocation) } \\
*\end{array}$ \\
\hline $\begin{array}{l}\text { Basis for } \\
\text { Allocation }\end{array}$ & $\begin{array}{c}\text { Input } \\
*\end{array}$ & Output & $\begin{array}{c}\text { Input } \\
\text { Output }\end{array}$ & $\begin{array}{l}\text { Basis for Allocation does not apply to } \\
\text { auctions }\end{array}$ \\
\hline
\end{tabular}

${ }^{*}$ Indicates design feature combinations that have been most commonly used to date.

The first dimension is the distribution method, accomplished by either allocation to sources without charge (free allocation) or by an auction. This report uses the term "distribution" to mean either one of these methods, and the term "allocation" or "free allocation" to refer to distribution of allowances without charge. The second dimension is the frequency of distribution: one time (grandfathering) or periodic reallocation. The third is the basis for allocation - typically based on heat input or generation output.

\subsubsection{Method of Allowance Distribution}

There are two primary options for allowance distribution: free allocation or auction. Under allowance allocation programs, the government distributes allowances in a free allocation to affected sources. It is free in the sense that there is no charge for the allowances, other than possible nominal administrative charges, though of course the allowances have value in the market. This system has been used in emission trading programs to date. Affected industry prefers this approach because most allowances do not need to be purchased. This approach also avoids 
the policy question of what to do with the income from an allowance auction. Allocation can also create advantages for those who receive free allowances because they are a valuable commodity that can be sold in a market. Allocation does not necessarily change current compliance actions, but it can change plant profitability (and amount of generation), asset valuation, and future investment decisions. It therefore can create incentives or biases. For example, differences in allocation between new and existing plants or among different fuel types may provide different benefits depending on plant vintage or fuel.

Under an auction, affected plants and others have the opportunity to purchase the available allowances in an open auction. Once purchased, allowances could be traded on a secondary market. All generators must pay up-front for all allowances, so there is no free allocation under a pure auction, ${ }^{j}$ consistent with the "polluter pays" principle. All emitters in the program have an equal position in the auction, so the auction does not create any bias.

Economists generally consider auctions to be the most economically efficient distribution mechanism because each participant makes unbiased tradeoffs among investment in technology, fuels, or allowances [11]. Also, the auction generates revenue that the government can redistribute in ways that offset the impacts of the regulation or meet other policy goals. It is also simple in that the government does not have to determine, track, and administer the basis for allocation (such as heat input or generation output).

Despite these theoretical benefits, auctions are not widely used as distribution methods under cap and trade programs, likely because they appear politically unattractive [12]. Under an auction, the affected industry incurs up-front costs to purchase allowances, rather than receiving a free allocation. Also, there may be controversy over what constitutes a beneficial use of auction revenues. ${ }^{\mathrm{k}}$

Although auctioning all allowances has not been implemented in cap and trade programs to date, auctioning some portion of the allowances to ensure market liquidity or to generate income is a more accepted part of cap and trade programs. The Title IV $\mathrm{SO}_{2}$ trading program auctions a few percent of the allowances each year to promote liquidity and price discovery. More recently, the Regional Greenhouse Gas Initiative (RGGI) has proposed a minimum set-aside of $25 \%$ of the allowances in each state that can be sold to raise funds for energy efficiency and other beneficial programs for the public good [13].

\footnotetext{
${ }^{\mathrm{j}}$ It is possible to adopt hybrid distribution systems that are combinations of the options discussed here, such as combinations of auctions and free allocations. This analysis addresses only the individual options to more clearly illustrate the differences among them.

${ }^{\mathrm{k}}$ State experiences with Clean Energy Funds could inform the use of auction funds as an incentive for renewable energy, if that policy were selected. For example, see p. 13 of Clean Energy Funds: An Overview of State Support for Renewable Energy. Bolinger, Mark, and Ryan Wiser (2001). LBNL-47705. Berkeley, CA: Ernest Orlando Lawrence Berkeley National Laboratory. April 2001. http://eetd.lbl.gov/EA/EMS/reports/47705.pdf. Accessed April 7, 2006.
} 


\subsubsection{Frequency and Basis for Distribution}

The second parameter, the frequency of distribution, determines whether the allowances are distributed only once or whether they are periodically reallocated or "updated." Allocation and auction can both occur as one-time or updating programs, although auctions are usually envisioned as updating programs. The third parameter is the basis for the allocation (heat input or generation output), which only applies under free allocation programs and is irrelevant to auctions.

Under grandfathering or one-time distribution, the allowances are allocated or auctioned only once, at the beginning of the program. The allocation basis can vary but does not affect future behavior and so is less important than under the updating approach. The acid rain $\mathrm{SO}_{2}$ trading program uses grandfathering, with allocation based on historical heat input. The plants that received allowances will continue to receive them (unless the program is changed) regardless of their emissions or operation, even if they shut down. New plants will never receive allocations. Grandfathering with free allocation provides financial benefit to the initial allocation group regardless of their emissions, efficiency, or other attributes. Those who are not in that group are at a greater financial disadvantage than if they had received allowances.

Under an updating system, the allowances are periodically redistributed (typically every 1 to 3 years). Most auction systems are envisioned as updating systems in which the allowances are auctioned every year.

Compared to grandfathering or one-time allocation, an updating system means that the basis for allocation has greater influence on decisions about how to operate the plant. A variety of different approaches can be used to determine the basis for the allocation, but the heat input or power generation output are most commonly used. The basis will be determined from each plant's data in the few years prior to the redistribution. In each year, each plant's allocation will be proportional to its share of total heat input or generation during baseline years. For example, if a plant generates $1 \%$ of the total power generated by affected plants, it would receive $1 \%$ of the allowances in an output-based system. Allocation typically occurs several years in advance to provide some certainty. For example, in Year Four of a program, allowances would be allocated for Year Seven based on average operation in Years One through Three.

Since new plants do not have a history of operation on which to base their allocation, an updating program typically includes a new source set-aside. This is a small pool of allowances that can be allocated to new plants until they have an operating history, at which time they become part of the normal allocation pool. ${ }^{1}$

The updating system is more work for regulators than grandfathering since the allocation occurs every 1 to 3 years instead of just once at the beginning of the program. The basic calculations are simple, but the process can be time-consuming, and the heat input or generation data must be

\footnotetext{
${ }^{1}$ A new source set-aside could be used under a grandfathering system, but because new plants never enter the main allocation pool under grandfathering, the new source set-aside would need to be sized to accommodate all future generation growth.
} 
collected, tabulated, and checked. Quality assurance and quality control of all data must meet high standards because each plant's allocation contributes to the calculation of the allocation for all other plants, so an error in any single facility's numbers affects others as well.

Updating allocation has several effects. One of the most important is that it brings new sources into the program as they begin to operate. It also phases older plants out of the program as they reduce or cease operation. If reallocation is based on an operating parameter such as heat input or output, it can affect decisions about future operation of affected plants. Depending on the program design, this can be used to promote policy goals (as discussed in Chapter 4).

The choice of whether to allocate allowances based on heat input or generation output is one of the more contentious allocation issues. It can be an issue for a grandfathering or updating allocation program, but it is more important for an updating program because the allocation is repeated and continues to affect future actions. In any year, the operation of the plant will affect the next allocation. Thus, the updating allocation creates incentives for certain behaviors. If the allocation is based on heat input, it rewards increased heat input. If it is based on generation, it rewards increased generation. In effect, an input-based system rewards fuel consumption while an output-based system rewards efficiency in generation. ${ }^{\mathrm{m}}$

\footnotetext{
${ }^{\mathrm{m}}$ Economic modeling studies suggest that updating output-based allocation provides an "output subsidy" that encourages increased generation output, which could increase allowance prices. See Reference 11.
} 


\section{Implications: Policymaker and Wind Generator Perspectives}

Before addressing methods for including wind generation in cap and trade programs, we briefly examine implications of this policy option from the perspectives of public policymakers and wind generators. Public policymakers expect that including renewable generation in cap and trade programs will provide an incentive for renewable energy, and they cite environmental and economic public benefits that they expect to achieve as the primary rationale for including renewable energy in cap and trade programs. Wind generators could benefit from cap and trade programs through several different mechanisms discussed below.

\subsection{State and EPA Rationales for Including Renewable Generation in Cap and Trade Programs}

Public policymakers in states that have included renewable generation in cap and trade programs often view this as an incentive that will provide environmental and economic public benefits. In its Guide to Action, a document prepared for state regulators and policymakers, EPA has described the potential environmental and technology innovation benefits of using output-based standards to promote cleaner, more efficient generation [14]. And in July 2004, NARUC adopted a resolution supporting the inclusion of energy efficiency and renewable energy in cap and trade allowance allocations, citing the fuel diversity, national security, and emissions reductions benefits of these technologies (see full resolution in Appendix B).

In addition, several states that have created energy efficiency and renewable energy (EE/RE) setasides under the $\mathrm{NO}_{\mathrm{x}}$ Budget Trading Program have indicated that they have done so for environmental and economic benefits (see Appendix $\mathrm{C}$ for specific language). For example, Massachusetts specifically cited reduced compliance costs and general economic benefits as the rationale for developing its EE/RE set-aside, while Indiana also noted the electricity system reliability benefits. New York's State Energy Plan emphasized the environmental benefits of its $\mathrm{EE} / \mathrm{RE}$ set-aside, noting the benefits of year round $\mathrm{NO}_{\mathrm{x}}$ reductions as well as carbon reductions. Elsewhere, the New York State Energy Research and Development Authority has studied the effects of renewable electricity generation and noted potential economic benefits [15].

In addition to the states implementing EE/RE set-asides under the $\mathrm{NO}_{\mathrm{x}}$ Budget Program, several other states have considered or plan to include renewable generation in their implementation of the CAIR. For example, Minnesota has proposed a 15\% EE/RE set-aside under the CAIR for a number of reasons, including that it will support the state's renewable energy policies and goals, provide a financial incentive to support the development of new renewable energy resources, and benefit the state and local economy [16].

\subsection{How Cap and Trade Programs Can Benefit Wind Generators}

This section explores the methods by which wind generators could benefit from participating in cap and trade programs. Including wind generators in a cap and trade program means allocating some portion of allowances or proceeds of allowance sales to them.

The wind generators can gain additional income by selling allowances that they receive in an allocation because they do not produce any direct emissions. Thus allocation of allowances to wind generators creates a market-based incentive for increased development of wind capacity. Alternatively, some wind generators may retire the emission allowances to make emissions 
reductions claims or seek higher revenue streams through compliance with renewable energy mandates (if required) or voluntary retail renewable energy markets.

We examine three mechanisms by which wind generators can benefit from inclusion in cap and trade programs:

- Selling the allowances back into the allowance market

- Retiring or bundling allowances with other renewable energy attributes ${ }^{\mathrm{n}}$ to participate in voluntary retail renewable energy markets

- Retiring the allowances to create creditable emission reductions.

The first of these mechanisms is not likely to reduce total emissions of the capped pollutant below the cap amount in the near term. The other mechanisms would reduce total emissions below that level because they involve retirement of allowances.

\subsubsection{Selling Allowances into the Market for Emission Allowances}

Once wind generators receive allowances under a cap and trade program, they can receive value for the emission allowances (for example, by selling the allowances into the market). If an emitting generator buys these allowances and uses them for compliance, then the allowances that were allocated to the wind generator will not have reduced total emissions of the capped pollutant below the level established by the cap. For illustration, the value of a $\mathrm{NO}_{\mathrm{x}}$ allowance is currently approximately $\$ 2000$ per ton $[17,18]$. This translates to approximately $\$ 1.50$ per megawatt-hour (MWh) for wind generation, depending on the allocation method (see Chapter 4). While small on a per-MWh basis, this amount could be significant in aggregate if it is received annually, over the lifetime of the project. This revenue stream could facilitate the financing of wind generation projects that are currently on the margin of competitiveness. Of course, the value would be larger if the total value of the revenue stream from allowances were greater, as might be anticipated under possible future cap and trade programs for $\mathrm{CO}_{2}$ reduction. In addition, revenues could be more substantial if generators are able to participate in allowance markets for multiple pollutants (e.g., $\mathrm{NO}_{\mathrm{x}}$, mercury, $\mathrm{SO}_{2}, \mathrm{CO}_{2}$ ).

\subsubsection{Retiring or Bundling Allowances to Participate in Voluntary Retail or Compliance Renewable Energy Markets}

An alternative to selling allowances into the emissions market is to retire them or "bundle" them with the renewable energy or renewable energy attributes to serve consumers who make voluntary purchases of renewable energy in voluntary retail renewable energy markets. Retirement of allowances may also be necessary to participate in markets or programs under renewable energy mandates if these mandates prohibit separation of the environmental attributes of renewable energy that the allowances represent.

Generators may sell renewable energy or its attributes to consumers interested in supporting renewable energy development. Customers can make voluntary purchases of renewable energy in

\footnotetext{
${ }^{\mathrm{n}}$ Renewable energy attributes can be sold separately from the generation. See discussion in text below.
} 
those markets where Green Power is available as "delivered product," meaning that the renewable electricity is on the same physical system as the customer. Alternatively, throughout the United

States, customers can choose to buy a commodity that represents the other attributes of renewable generation besides the electricity itself. These attributes are generally referred to as renewable energy certificates (RECs). In these voluntary markets, some consumers purchase renewable energy, or more commonly its attributes, for its air quality or carbon reduction benefits. To make emission reduction claims for capped pollutants, generators must retire allowances or transfer them with the renewable energy. ${ }^{\circ}$ Some organizations that certify or track the sale of renewable energy in voluntary markets require that emission allowances be retired or transferred to the enduser as a stipulation of certification. ${ }^{p}$

Generators may also sell renewable energy or RECs to meet state renewable energy mandates. More than 20 states have established mandatory Renewable Portfolio Standards (RPSs) that require electricity suppliers to obtain a certain percentage of their electricity generation from renewable energy sources [19]. Whether allowances must be included with the renewable energy or RECs for compliance with state RPS policies depends on the implementing rules in each state. In states where the RPS rules do not explicitly require emission allowances to be retired with RECs for RPS compliance, wind generators could sell RECs for RPS compliance and also sell emission allowances separately in the allowance market. In other states, allocated emission allowances must be retired to meet the requirements of the RPS. This can be accomplished by bundling the allocated allowances with the RECs used for RPS compliance, but this requires that administrative mechanisms exist to coordinate across potentially different schedules for the two programs. Bundling and retiring allowances with RECs for compliance represents a policy choice to reduce emissions below the cap-mandated level.

\subsubsection{Retiring Allowances to Create Creditable Emission Reductions}

Some state or local governments have considered using emission reductions created by renewable generators under a cap and trade program as a potential contribution to meeting National Ambient Air Quality Standards (NAAQS). This can be done by requiring or paying renewable generators to retire any allowances that might be allocated to them. These retired allowances represent emission reductions to levels below the cap level and might be usable by the state as part of the State Implementation Plan (SIP) to demonstrate attainment of the NAAQS. ${ }^{\mathrm{q}}$ The EPA provides

\footnotetext{
${ }^{\mathrm{o}}$ Wind generators or renewable energy marketers should ensure they are meeting emission reduction claims by making the appropriate retirement of allowances, if necessary.

${ }^{\mathrm{p}}$ For example, Green-e, which is the leading certifier of renewable energy in U.S. voluntary purchase markets, requires that "to be eligible [for certification], a REC or energy product must, to the extent possible based on current law, contain all of the environmental attributes that were associated with that unit of renewable generation when it was generated." (See the Green-e National Standard at www.green-e.org/pdf/Green-e_National_Standard.v1.pdf, modified June 19, 2006.) In addition, the U.S. EPA Green Power Partnership requires its partners, which include the vast majority of nonresidential voluntary renewable energy purchasers, to retire the emissions attributes of their renewable energy purchases. (See partnership requirements at www.epa.gov/greenpower/pdf/program_requirements_memo.pdf, U.S. Environmental Protection Agency, Green Power Partnership, Green Power Partnership Program Requirements. April 2004.)

${ }^{\mathrm{q}}$ Choosing this approach as a SIP measure would imply that the air quality planners for the local non-attainment area are placing priority on reducing emissions throughout the cap and trade region or that the renewable generation in question would reduce emissions at specific power plants that affect the non-attainment area.
} 
guidance on SIP credit for energy efficiency and renewable energy projects [20]. For example, Montgomery County in Maryland used a purchase of wind generation and associated retirement of the $\mathrm{NO}_{\mathrm{x}}$ allowances to help demonstrate compliance with national ozone standards [21].

In summary, state policymakers include wind generation and other renewable generation in cap and trade programs to provide an incentive for technologies that they believe will provide environmental and economic benefits. Wind generators could benefit through several different mechanisms. Whether the policymakers' goals are achieved and the potential benefits of these programs to society and to wind generators are realized will depend on effective implementation, the subject of the next section. 


\section{How Can Wind Generation Be Included in Cap and Trade Programs?}

Once the decision has been made to include wind generators in a cap and trade program, program design must be determined. In this section, we examine the two approaches for including wind generators in a generation-based cap and trade program that are now used or appear most likely to be used in the near-term for CAIR ${ }^{\mathrm{r}}$ :

- Renewable energy set-asides

- Direct output-based allowance allocation to wind generators.

This chapter addresses the purpose and design of these structures, as well as the advantages and disadvantages of each one.

\subsection{Renewable Energy Set-Asides}

Under a renewable energy set-aside, a regulating agency allocates a portion of the total emission allowances to support specific energy technologies, such as renewable energy, energy efficiency, and sometimes fuel cells or other advanced technologies. This portion of allowances is reserved and distributed to the eligible technologies as an added incentive for development outside of the standard allocation process to conventional sources.

Major examples of these set-asides include the Conservation and Renewable Energy Reserve that was established during Phase I implementation of Title IV of the Clean Air Act Amendments of 1990 [22] and the $\mathrm{NO}_{\mathrm{x}}$ Budget Trading Program opportunity for states to establish energy efficiency/renewable energy (EE/RE) set-asides, as described in EPA rulemaking [23] and guidance [24]. A previous NREL report provides a comprehensive overview of the role of renewable energy in federal air quality regulations, including a summary of issues that affected participation in the Conservation and Renewable Energy Reserve under the $\mathrm{SO}_{2}$ trading program [25].

In response to the EPA rulemaking that established the $\mathrm{NO}_{\mathrm{x}}$ Budget Trading Program, seven states have established or sought to establish EE/RE set-asides in that program. An EPA summary [26] of state EE/RE set-asides describes the details of these programs.

\subsubsection{Design of a Renewable Energy Set-Aside}

There are several key components to the design of a renewable energy set-aside, including:

- Definition of eligible technologies and projects

- Size of set-aside and dealing with oversubscription

\footnotetext{
${ }^{\mathrm{r}}$ Other approaches, such as auctions or load-based allocation, are under development for greenhouse gas control programs but are not discussed here in detail. For example, California's load-based approach for carbon emissions will affect the market for renewable generation, but specific mechanisms have not been determined. In addition, an auction process is under development for the Regional Greenhouse Gas Initiative in the Northeast.
} 
- Distribution procedure

- Administrative procedures.

These components are discussed below. Section 5 provides actual regulatory language for implementation of a renewable set-aside under the CAIR.

\section{Definition of Eligible Technologies and Projects}

Qualifying Technologies. The set-aside regulation must identify the qualifying generating technologies that are eligible to receive allowances. The list of eligible technologies will depend on the policy decision about where to focus incentives, and usually includes generation from wind, small hydropower, solar, tidal, and other non-emitting renewable technologies. Emitting renewable generation, such as biomass or landfill gas, can be included, and states have also sometimes included advanced low-emitting technologies, such as fuel cells. Since biomass and small emitting facilities are usually excluded from the emission cap programs, adding them to the allocation system may require including them in the emission cap as well to account for their emissions.

Project Vintage and Size. In addition to the technology, the definition can address the project vintage and size. If the main goal is to promote the development of new renewable generation, programs may limit the applicability to projects that come online after the proposed promulgation of the program. This also reduces possible concerns over a "windfall" allocation to long-standing generating resources. That said, including some recent-vintage existing renewable projects can help to make them more viable in the electricity market and provide financial support to active renewable energy development firms. This trade-off may be a reason for states to consider "fine-tuning" the applicability dates in their rules.

Allocation to New Units. Under either an input- or output-based allocation, ${ }^{\mathrm{s}}$ the generator must establish an historic baseline on which to base the allocation (typically 3 years of operation). While this baseline is being established, the generator cannot receive allocations. Most programs establish a new source set-aside to provide allowances to new generators that have not established their baseline. ${ }^{t}$

Directly allocating allowances to new wind generators on a similar basis as other new sources provides an incentive for new wind energy development, but does not assist existing wind energy generating units. While such units may not rely on allowance value for financing, as new units might, they can displace emissions and may wish to make emission-reduction claims. Under a cap and trade program, non-emitting generators, such as wind, cannot claim to reduce total emissions unless they obtain and retire allowances.

Size. Most cap and trade programs apply to conventional generators larger than 25 MW to limit the administrative burden on regulators of dealing with many small generators with relatively

\footnotetext{
${ }^{\mathrm{s}}$ See Section 2 for explanations of input and output basis.

${ }^{t}$ There was no new source set-aside under the Title IV SO2 cap and trade program. Therefore, new units must purchase allowances from existing units.
} 
low emissions. Renewable energy set-asides usually do not have to limit their applicability to such large projects but may impose a minimum allocation of one whole allowance. For some renewable energy generation, especially wind generation, it is also important to distinguish between generating units and projects. Wind projects often comprise a large number of small generating units (e.g., 1- to 2-MW turbines). To avoid excluding such composite projects and to limit the administrative burden for regulators and generators, it is important to allocate allowances to an entire project rather than to individual turbines. Further, set-asides can allow aggregation across projects to reduce transaction costs while including and encouraging the greatest number of renewable projects.

\section{Size of Set-Aside and Addressing Oversubscription}

A set-aside does not increase the overall level of the cap; it reserves a percent of the current allowance pool for specified technologies, such as renewable energy. As noted above, most setasides to date have been a few percent of the total allocation pool. This is often sufficient to cover existing and near-term renewable energy generation; however, it may not be sufficient to keep up with longer-term growth. As installed capacity of wind and other renewable energy generation increases, it may exceed the available set-aside allowances. If the state has a renewable portfolio standard, comparison of that goal with the size of the renewable energy setaside could be one indicator of the likelihood and timing of oversubscription. Establishing an initial set-aside that adequately allows for future growth will help keep administration simple and consistent. However, because set-asides reduce the number of allowances allocated to conventional generators, establishing a set-aside that is large enough to accommodate growth may be politically difficult.

Addressing oversubscription is one of the main potential problems with a set-aside approach; however, only Massachusetts has actually experienced oversubscription to date. If and when renewable generation starts to exceed the available set-aside allowances, there are several possible responses:

- One alternative is to prorate the available allowances as the renewable generation grows. This means that the allocation becomes less valuable to any individual wind project over time and the value of the set-aside as an incentive for new development is reduced.

- Another approach is to limit the number of years that a renewable project can receive allowances from the set-aside. Under this approach, projects are cycled in and out of the program, making room for new projects to come in. Again, this reduces the ability of the program to provide long-term economic value to new renewable projects.

- Another alternative is to increase the size of the set-aside once it becomes oversubscribed.

A less contentious issue is how to handle an undersubscribed set-aside. The most common approaches are to reallocate the unused allowances to conventional generators or to bank them for future allocation to eligible renewable projects. Both of these approaches have been successfully used in state set-aside programs. 


\section{Distribution Procedure}

Most current trading programs allocate allowances for free to conventional units based on heat input times an allocation factor. The allocation factor is usually the nominal value on which the cap is based. For example, the $\mathrm{NO}_{\mathrm{x}}$ Budget Trading Program cap is based on emissions of 0.15 $\mathrm{lb} / \mathrm{MMBtu}$, and this same factor is used as the nominal allocation factor for most state allocation systems. The actual allocation is rarely exactly equal to this factor because the allocations must be normalized to meet the cap, allowing for growth in heat input, set-asides, and other design factors.

Renewable generators cannot use the same approach if they do not have heat input. However, a common approach is to convert the input-based allocation factor to an output-based factor and apply it to the renewable generation. For example, $0.15 \mathrm{lb} / \mathrm{MMBtu}$ could be converted using a typical power plant heat rate of $10,000 \mathrm{Btu} / \mathrm{kWh}$ to $1.5 \mathrm{lb} / \mathrm{MWh}$. Then renewable generators would receive an allocation of $1.5 \mathrm{lb} / \mathrm{MWh}$ generated. This method has the advantages of being straightforward, easy to calculate, and consistent with the approach taken for conventional generators.

A variation on this approach is to calculate the emissions rate of the generating resources that would actually be displaced by renewable generation and use that rate as the allocation factor. While this can provide an allocation more directly linked to actual emissions, the displacement calculation can be complex and change from year to year, potentially adding to the cost, complexity, and controversy of the set-aside allocation. One way to minimize these concerns is to use a standard allocation factor but allow generators the option to calculate an actual allocation factor if they wish.

Another issue related to allocating allowances is how to track electric output for use in the allocation process. The most effective approach seems to be to require generators to report their generation directly as part of their application. Renewable generators typically measure and record their generation with billing-quality meters for wholesale sales, net metering, or other commercial purposes. This monitoring can be used to document generation for allocation purposes.

Typically, allowance allocations within the set-aside must be recalculated periodically, anywhere from annually to every few years. This is true for two reasons. First, new generators will be entering the program and need to receive allowances. In some cases, the addition of new generators may lead to oversubscription of the set-aside, requiring allowances to be prorated among all participating renewable energy generators. Second, new projects often generate more electricity after the first year of operation after equipment goes through shakedown and contracts are established in the market.

\section{Administrative Burden}

Excessive transaction costs can prevent a set-aside program from achieving its full potential benefit. Renewable developers and operators are typically not familiar with air quality regulations, procedures, schedules, and requirements of trading programs and broader air regulator programs. Air quality regulators are not always familiar with zero-emitting renewable energy technologies, projects, and accepted monitoring procedures. Going through a learning 
process on both sides requires time and effort. Some states that established set-asides under the $\mathrm{NO}_{\mathrm{x}}$ Budget Program have not yet established the rules governing the application process.

Some of the components that can simplify a set-aside program and reduce the potential burden include:

- Establishing a simple and straightforward allocation procedure; for example, by establishing a default allocation rate

- Designing a simple and clear application form

- Allowing aggregation of small projects without burdening the state; for example, by requiring a single application from one representative of the aggregated project

- Providing a simple and clear procedure for continuing allocation once a facility has entered the program

- Providing outreach to inform potential participants about the program.

\subsubsection{Advantages of a Renewable Energy Set-Aside}

Renewable energy set-asides are the best known and most widely applied method for allocating allowances to renewable generators. They have been established under several programs (the Title IV $\mathrm{SO}_{2}$ trading program and the $\mathrm{NO}_{\mathrm{x}}$ Budget Trading Program) and in at least seven states. A renewable energy set-aside provides a concrete number of allowances that are specifically allotted to support renewable energy sources. Therefore allowances can be allocated to renewable generators immediately at the start of operation, whereas under a direct allocation approach there may be a lag between operation and allocation depending on baseline requirements.

Because the number of allowances reserved for renewable energy remains unaltered over time under a set-aside, it creates certainty for both the renewable energy generator regarding the number of allowances that are available and to the fossil fuel generators regarding the number of allowances that will be allocated. This certainty may be easier to accept politically than other approaches that allocate an uncertain number of allowances in proportion with generation output.

Because a set-aside pool is not affected by growth in the fossil fuel electric generating sector, renewable energy sources do not have to compete with fossil fuel sources for allowances. So from the renewable generator perspective, a limited but exclusive set-aside is advantageous. Depending on the size of the set-aside, in the initial years of the cap and trade program, individual renewable energy generators have some certainty regarding the number of allowances they will receive by using expected generation and the standard allocation rate, which allows for a more likely inclusion in project financing. However, this certainty is removed if renewable energy generation outgrows the size of the set-aside. 


\subsubsection{Disadvantages of a Renewable Energy Set-Aside}

Even though a set-aside guarantees the number of allowances available to renewable energy sources as a whole, there are two primary drawbacks to a set-aside relative to other distribution methods:

- There is a limit on the long-term availability of allowances for wind and other renewable energy generators.

- The transaction cost for receiving allowances may be high compared to other approaches to distribution.

- Uncertainty associated with the application process reduces the financial value of the allowances to wind and other renewable energy generators.

Most set-asides have been set at $1 \%$ to $5 \%$ of the total allowance pool. While this may be adequate to accommodate the market in the near term, in the longer term it may not be sufficient to provide allowances for a growing wind power sector. This leads to competition among the wind generators for the limited pool of allowances, reducing the value of the allowances. If wind generation outgrows what can be accommodated by the set-aside, allowances are likely to be distributed on a prorated basis, decreasing the number of allowances each generator receives and reducing the program's value to new projects. Alternatively, the program may limit the years of eligibility in the program for wind generators, dropping them after a few years to allow newer projects to come into the program. Either way, the value of the set-aside to wind developers is diminished over time. Because of this, a set-aside program is not as valuable to new wind energy development as allocation of allowances on the same basis as other energy sources from the main allowance pool.

Relative to other allowance distribution methods, a set-aside program also creates administrative complexity for the regulating agency and the electric generator because it treats renewable generation separately from the rest of the cap and trade program. Typically, allocations to conventional generators are automatic, but wind and other renewable energy generators must apply to receive set-aside allowances. In some cases, they must reapply every year. This application process can be an administrative burden and create a transaction cost that must be compared to the expected value of allowances that might be allocated to determine whether it is worthwhile to apply. The regulating agency must administer an entirely separate program when using a set-aside, requiring additional resources to review and verify set-aside applications and to allocate allowances appropriately across the wind generators. Transaction costs for both regulators and generators can reduce the effectiveness and value of a set-aside.

In addition, the uncertainty associated with the application process means that renewable energy generators cannot count on the value of allowances until after the application is approved. This reduces the effective value of the allowances. Uncertainty related to the application process is particularly high if the requirements of that process have not been formally established, as is the case in some states that adopted set-asides for the $\mathrm{NO}_{\mathrm{x}}$ Budget Trading Program. 
Despite these disadvantages, some states have had full subscription of their set-aside program under the $\mathrm{NO}_{\mathrm{x}}$ Budget Trading Program. The next section discusses some specific results for wind energy projects.

\subsubsection{Experience with EE/RE Set-Asides}

The only active emission allowance trading market today with renewable energy set-asides is the $\mathrm{NO}_{\mathrm{x}}$ Budget Trading program. The $\mathrm{NO}_{\mathrm{x}}$ Budget Trading Program took effect in 2003 to reduce emissions of $\mathrm{NO}_{\mathrm{x}}$ in 22 eastern states and the District of Columbia. This program aims to reduce the production of ground-level ozone ( $\mathrm{smog}$ ), of which $\mathrm{NO}_{\mathrm{x}}$ is a precursor. Affected states must limit $\mathrm{NO}_{\mathrm{x}}$ emissions during the ozone season, from May 1 until September 30 every year. Of the 23 affected jurisdictions, only six currently have a set-aside for EE/RE projects (see Table 2): Indiana, Massachusetts, Maryland, New Jersey, New York, and Ohio. Missouri has established a set-aside to take effect when it enters the program in 2007.

Table 2. Summary of SIP Call Set-Aside Parameters

\begin{tabular}{|c|c|c|c|c|c|c|c|c|c|}
\hline & \multirow{2}{*}{$\begin{array}{c}\text { Size of } \\
\text { Annual } \\
\text { Set- } \\
\text { Aside } \\
\text { (Tons) } \\
\end{array}$} & \multirow{2}{*}{$\begin{array}{c}\% \text { of } \\
\text { Total } \\
\text { Budget }\end{array}$} & \multirow{2}{*}{$\begin{array}{c}\text { Allocation } \\
\text { Basis }\end{array}$} & \multirow{2}{*}{$\begin{array}{l}\text { Length of } \\
\text { Allocation }\end{array}$} & \multirow{2}{*}{$\begin{array}{c}\text { Generator } \\
\text { Online Date }\end{array}$} & \multicolumn{4}{|c|}{ Applicability } \\
\hline & & & & & & $\mathrm{RE}$ & $\mathrm{EE}$ & Biomass & CHP \\
\hline Indiana & 1,115 & $2 \%$ & $\begin{array}{l}1.5 \mathrm{lbs} / \mathrm{MWh}, \\
\text { discounted by } \\
75 \% \text { for } \\
\text { projects owned } \\
\text { by affected } \\
\text { entities }\end{array}$ & $5 \mathrm{yrs}$ & $\begin{array}{c}\text { within } 2 \text { yrs } \\
\text { of request }\end{array}$ & $\mathrm{x}$ & $\bar{x}$ & & $\mathrm{x}$ \\
\hline Maryland & 463 & $3 \%$ & $2.5 \mathrm{lbs} / \mathrm{MWh}$ & NA & $\begin{array}{c}\text { on or after } \\
5 / 1 / 00\end{array}$ & $\mathrm{x}$ & $\mathrm{x}$ & & \\
\hline Massachusetts & $\begin{array}{c}643 \text { tons, } \\
768 \text { tons } \\
\text { allocated } \\
\text { to date }\end{array}$ & $5 \%$ & $\begin{array}{c}1.5 \mathrm{lbs} / \mathrm{MWh}_{\mathrm{e}} \\
0.44 \\
\mathrm{lbs} / \mathrm{mmBtu} \\
\text { useful thermal } \\
\text { output }\end{array}$ & $\begin{array}{l}\text { No limit for } \\
\text { RE; } 7 \text { years } \\
\text { for EE }\end{array}$ & $\begin{array}{c}\text { after } \\
12 / 31 / 99\end{array}$ & $\mathrm{x}$ & $\mathrm{x}$ & & $x^{*}$ \\
\hline New Jersey & 410 & $5 \%$ & $1.5 \mathrm{lbs} / \mathrm{MWh}$ & No limit & $\begin{array}{c}1992 \text { and } \\
\text { after }\end{array}$ & $\mathrm{x}$ & $\mathrm{x}$ & & \\
\hline New York & 1,241 & $3 \%$ & $1.5 \mathrm{lbs} / \mathrm{MWh}$ & $5 \mathrm{yrs}$ & after $5 / 1 / 03$ & $\mathrm{x}$ & $\mathrm{x}$ & $\mathrm{x}$ & \\
\hline Ohio & 454 & $1 \%$ & $1.5 \mathrm{lbs} / \mathrm{MWh}$ & $5 \mathrm{yrs}$ & & $\mathrm{x}$ & $\mathrm{x}$ & $\mathrm{x}$ & $x^{*}$ \\
\hline Missouri $^{* *}$ & 134 & $1 \%$ & $1.5 \mathrm{lbs} / \mathrm{MWh}$ & $5 \mathrm{yrs}$ & $\begin{array}{c}\text { after } \\
5 / 1 / 2006\end{array}$ & $\mathrm{x}$ & $\mathrm{x}$ & $\mathrm{x}$ & $\mathrm{x}$ \\
\hline
\end{tabular}

$\mathrm{NO}_{x}$ Budget units not eligible. "Starting 2007

The set-asides are typically between $1 \%$ to $5 \%$ of the total $\mathrm{NO}_{\mathrm{x}}$ allowance budget. The types of $\mathrm{EE} / \mathrm{RE}$ projects considered to be eligible vary somewhat by state but include:

- Zero-emitting renewables, such as wind and solar 
- Energy efficiency projects such as retrofitting lighting, air conditioning, and other systems with more efficient equipment

- Renewable projects burning biomass

- Combined heat and power (CHP) projects.

Projects typically are only eligible if they are considered to be "new," with the definition of "new" varying by state from 1992 to 2003. Projects receive allowances in units of pounds of $\mathrm{NO}_{\mathrm{x}}$ per megawatt-hour (lbs/MWh) saved (by energy efficiency) or generated. The allocation factor is typically $1.5 \mathrm{lbs} / \mathrm{MWh}$ saved or generated, which is based on the nominal emission cap. Depending on the state, a project may receive allowances for up to 5 years or more but must reapply each year. Based on current prices for $\mathrm{NO}_{\mathrm{x}}$ allowances, the value of allocations is around $\$ 1.50 / \mathrm{MWh}[17,18]$.

\section{Experience with State Set-Aside Programs}

To assess the experience to date with EE/RE set-aside programs, interviews were conducted with state air regulators and wind energy developers who had existing or proposed projects in states with set-asides. In most states, the EE/RE set-asides have not been fully subscribed, and generally very few types of projects have benefited from them.

For instance, in Indiana, the program has not yet been fully utilized and only landfill gas projects have received allowances. Maryland has had applications from two wind projects but has not yet developed rules for the application process or granted allowances ${ }^{\mathrm{u}}$. Ohio has allocated allowances primarily to hydroelectric facilities, and also to one wind project, with 80 of the 454 allowances allocated for the 2006 ozone season. New Jersey typically allocates $10 \%$ to $12 \%$ of the allowances in the set-aside each year. To date, two landfill gas projects have received allowances, while most allowances go to energy efficiency projects. New York is now developing its rules for applications and has not allocated set-aside allowances to date. Massachusetts is the only state in which the set-aside is over-subscribed. There, as in New Jersey, most of the allowances go to energy efficiency projects, although two hydroelectric facilities have also received allowances.

Thus, set-aside programs offer very limited examples of allocating allowances to renewable generators in general and wind energy in particular. Interviews with wind project developers and state regulators identified several possible reasons why participation has been limited:

Conflict with State RPS Programs. In some states that have both allowance set-asides and renewable energy mandates, there can be a conflict between the provisions of the two programs that explicitly or implicitly requires developers to choose one or the other program. If the value of RECs under the RPS is higher than the value of the $\mathrm{NO}_{\mathrm{x}}$ allowances, developers are likely to choose the RPS rather than the $\mathrm{NO}_{\mathrm{x}}$ program.

\footnotetext{
${ }^{\mathrm{u}}$ Montgomery County in Maryland is purchasing some wind power, for which a number of allowances will be retired; however, this was negotiated outside of the set-aside program.
} 
For example, in New York, wind generators sell to the New York State Energy Research and Development Agency (NYSERDA) their rights to claim environmentally beneficial attributes of their electricity, as well as the right to transfer that right. Under this program, NYSERDA requires generators to include all emission credits with the sale; however, there is no explicit price adder for the allowances. Since there is no value placed on the allowances in this market, there is no incentive for wind developers to go to the effort of acquiring the $\mathrm{NO}_{\mathrm{x}}$ allowances and therefore none have done so. However, there could be value to acquiring allowances for wind generators selling to the voluntary (non-RPS) market. In addition, if there were surplus renewable generation beyond what is required to satisfy the RPS, there could be a value in acquiring $\mathrm{NO}_{\mathrm{x}}$ allowances so that environmental attributes of renewable generation could be sold outside the RPS. For the present, however, the structure of the RPS is effectively discouraging generators from participating in the $\mathrm{NO}_{\mathrm{x}}$ allowance program because the RPS policy is intended to reduce emissions. This in turn has caused some environmental regulators to believe that there is little interest in the set-aside program.

In some cases in other states where RPS and set-aside requirements were not in conflict, regulators or developers were under the false impression that they were. Air regulators, energy officials, and renewable energy developers do not consistently have a clear understanding of each others' regulations and contractual requirements. Confusion between regulatory requirements and contractual requirements further complicates understandings among these parties. Language establishing requirements is also unclear in some cases.

Rule Complexity and Delays. Most states have established their allowance set-aside programs and have received at least some applications. However, the process can be administratively slow and burdensome. A wind developer in Maryland reported that an application has been pending for several years as the state considers the appropriate treatment and pursues a rulemaking to establish the application procedure. It was reported that this process has also been slowed by pressure from incumbent utilities that are reluctant to see allowances diverted from the main allocation pool. Similarly, in New York, while the set-aside has been established for several years, the state is in the process of developing guidance and formal application documents and is not yet able to allocate the allowances.

Perceived Value of Allowance Set-Asides. At current allowance prices and allocation rates, $\mathrm{NO}_{\mathrm{x}}$ allowance set-asides are worth about $\$ 1.50 / \mathrm{MWh}(\$ 0.0015 / \mathrm{kWh})$ for renewable generators. While not inconsequential, this is not a large amount on a per-MWh basis, and may be insufficient to motivate applications. However, others noted that allowances can have a significant value as an aggregate amount over the life of the project and in combination with other incentives. Some wind developers viewed this as a temporary market condition, rather than a fundamental reason not to participate in a set-aside program. Many wind developers are looking forward to the expected higher value of $\mathrm{CO}_{2}$ allowances under possible future $\mathrm{CO}_{2}$ trading programs. They hope that set-asides under $\mathrm{NO}_{\mathrm{x}}$ programs will establish a precedent for such future programs.

Lack of Developer Knowledge of the Set-Aside Program. Some wind developers interviewed were unaware of potential eligibility of their projects for $\mathrm{NO}_{\mathrm{x}}$ allowance set-asides. As nonemitting generators, some developers do not think about the applicability and potential benefits of participating in an emission reduction program. 
Despite these problems, there seems to be growing interest in $\mathrm{NO}_{\mathrm{x}}$ set-aside programs (perhaps due to increasing awareness among wind developers). Although the set-aside in Missouri does not begin until 2007, a wind facility under development there plans to apply to the program. In Ohio, a wind facility is receiving two allowances, and its managers are happy with the EE/RE set-aside program. Their main concern is the potential tightening of the program, under which eligibility may be limited to facilities that began operation within the past 2 years. If this occurs, the wind facility in Ohio will no longer be eligible.

In general, the $\mathrm{NO}_{\mathrm{x}} \mathrm{EE} / \mathrm{RE}$ set-asides have not provided significant value to wind generators. Although one facility in Ohio is receiving allowances, the others contacted remain frustrated or even unaware of the set-aside program. Conflicting regulations, inadequate allowances, facility age constraints, lengthy application processes, or lack of awareness are reasons that wind generators have not pursued EE/RE set-asides.

\subsection{Direct Output-Based Allocation to Renewable Energy}

Another near-term alternative to allocating allowances to wind generators through a set-aside is to directly allocate them based on relative quantity of electricity generation as part of the primary allocation pool. That is, if the main pool of allowances is allocated based on electric output, renewable generators can receive their allocations on the same basis as other generators.

In a recent Clean Energy-Environment Guide to Action, the U.S. EPA highlights the benefits of output-based environmental regulations. Section 5.3 of the document states:

The goal of output-based environmental regulations is to encourage the use of fuel conversion efficiency and renewable energy as air pollution control measures...States utilize output-based environmental regulations to encourage efficient energy generation by leveling the playing field for fuel conversion efficiency and renewable energy as air pollution control measures. Historically, environmental regulations have been input-based, which does not account for the pollution prevention benefits of process efficiency, which encourages the use of more efficient generation approaches [14].

Shifting from a heat input- to a generation-output-based allocation system facilitates a cap and trade program including all generators on a neutral basis, regardless of fuel and emissions, which can provide a greater incentive for investment in both clean and efficient energy sources.

\subsubsection{Design of Output-Based Allocation to Wind Generators}

Design issues for output-based allocation to renewable generators include:

- Eligible technologies, size, and vintage

- Basis for allocation

- Timing of allocations

- New source set-aside. 


\section{Definition of Eligible Technologies and Projects}

A cap and trade program for emission reductions can allocate the allowances based on output generation (MWh) and specify the units eligible to participate. Instead of including only fossilfuel-fired units, as has been the case under previous cap and trade programs, eligible units can be expanded to include both fossil-fuel-fired and renewable energy electric generating units. State regulators will likely wish to define specific renewable energy sources to reflect their state's goals and resources. This process is essentially the same as for a renewable energy set-aside (see Section 4.1). Chapter 5 includes regulatory language for output-based allocation to wind generators under the CAIR.

\section{Basis for Allocation}

The allocation method will differ slightly depending on whether a pure output-based allocation is used or an allocation factor based on output. In the case of a pure output-based allocation to all sources, generating units can receive allowances based on their proportion of output, as calculated during a baseline period, which then may be updated. An alternative is to use an allocation factor, in pounds of emissions per MWh or $\mathrm{kWh}$. If the same allocation factor is used for all energy sources and allocations are prorated to achieve the cap, then the effective allocation will be the same as under a pure output-based allocation.

\section{Timing of Allocations}

Most cap and trade programs reallocate allowances periodically to bring new generators into the program. The timing of reallocation can range from every year to every 10 years. A 3- to 5-year reallocation is common. The allowances are typically allocated several years in advance to provide certainty to generators.

\section{New Source Set-Aside}

A new unit entering the program typically must establish several years of baseline operating data. It will then receive an allocation for an allowance vintage several years in the future. Thus there can be a lag of 5 or more years between initial commercial operation and the time that a unit actually receives allowances. Most programs fill this gap with a "new source set-aside." These allowances are based on the operation in the year immediately prior or are based on expected operation and prorated for actual operation at the end of the year. Under a direct outputbased allocation to wind generators, the wind generators would need to be included under the new source set-aside to receive allowances during their early years of operation.

\subsubsection{Advantages of Direct Output-Based Allocation to Wind Generators}

If output is selected as the basis for allocation of the main allowance pool, directly allocating allowances to new renewable energy generation including wind generation units provides clear support for new development of renewable resources. An output-based allocation method has the following advantages:

- Provides a more stable and consistent allocation stream for renewable sources, relative to a set-aside.

- Simplifies the allocation process and reduces administrative burden 
- Establishes a basis for allocation (output) that is neutral with respect to fuels and energy source

Output-based allocation is more stable and consistent than a fixed set-aside because new wind generators receive allocations from the main allowance pool, along with other generators. Therefore, renewable energy sources do not compete directly against each other for a fixed number of set-aside allowances. This provides greater certainty that allocations will be consistent over time, which increases the financial value of the allowances under output-based allocation relative to a set-aside.

Overall, an output-based method simplifies the allocation process for renewable energy compared to a set-aside. Generation data are easily collected as generators already track the information and state agencies already collect such data for other purposes. An output-based approach also eases the administrative process because all generators are allocated allowances using a single source of data. An output-based approach eliminates the need for regulating agencies to determine either a direct emission displacement rate or an allocation factor.

Finally, generation output is a unit of measure that is neutral for all generating units. Under an output-based allocation system that gives allowances to all generators at the rate per $\mathrm{kWh}$, there is no bias for or against any specific energy source based on vintage or fuel. An output-based system encourages development of the most fuel efficient energy sources, as well as renewable energy sources.

\subsubsection{Disadvantages of Direct Output-Based Allocation to Wind Generators}

The approach of output-based allocation to wind generators has not been implemented as part of the primary allocation under previous emission reduction cap and trade programs, so the lack of operational experience is a disadvantage. Also, because such a program could allocate more allowances to renewable generators than a set-aside, some incumbent conventional generators oppose output-based allocation, complicating its implementation. ${ }^{\vee}$

Output-based allocation as a design choice overall is subject to the criticism, from a theoretical economic standpoint, that it subsidizes and therefore encourages output. Economic modeling studies have shown results consistent with theory, that updating output-based allocation can increase generation. However, if output-based allocation has been selected for the main allowance pool, this potential disadvantage is separate from the decision of whether to include renewable generators in the main allocation.

On a more programmatic level, a full output-based program requires tracking of electricity output from all regulated sources. It may also include more, smaller renewable generators in the broader trading program, which may add complexity.

\footnotetext{
${ }^{\mathrm{v}}$ Opponents of other non-emitting generating technologies also may oppose any increased use of output-based allocation, and proponents of those technologies may seek to be included in output-based allocation that is open to all generators.
} 
In this section, we have identified the primary methods for including wind generation in cap and trade programs and explored their advantages and disadvantages. Next, we turn to the specific regulatory changes needed to incorporate wind generation into a particular program: the CAIR. 


\section{Incorporating Renewable Energy into the Clean Air Interstate Rule}

In March 2005, the U.S. EPA promulgated the Clean Air Interstate Rule (CAIR) (70 FR 25162, $5 / 21 / 05)$, which caps emissions in the 28 eastern states and the District of Columbia to significantly reduce the negative health and environmental impacts from nitrogen oxides $\left(\mathrm{NO}_{\mathrm{x}}\right)$ and sulfur dioxide $\left(\mathrm{SO}_{2}\right)$. The program will be implemented in two phases and is expected to reduce $\mathrm{NO}_{\mathrm{x}}$ emissions by $60 \%$ and $\mathrm{SO}_{2}$ emissions by $70 \%$ below 2003 levels at full implementation in 2015. States may be eligible to participate in an annual $\mathrm{SO}_{2}$, an annual $\mathrm{NO}_{\mathrm{x}}$ and/or ozone season $\mathrm{NO}_{\mathrm{x}}$ trading program (Figure 1), depending on whether the state needs to address $\mathrm{PM}_{2.5}$ nonattainment, ozone nonattainment, or both.

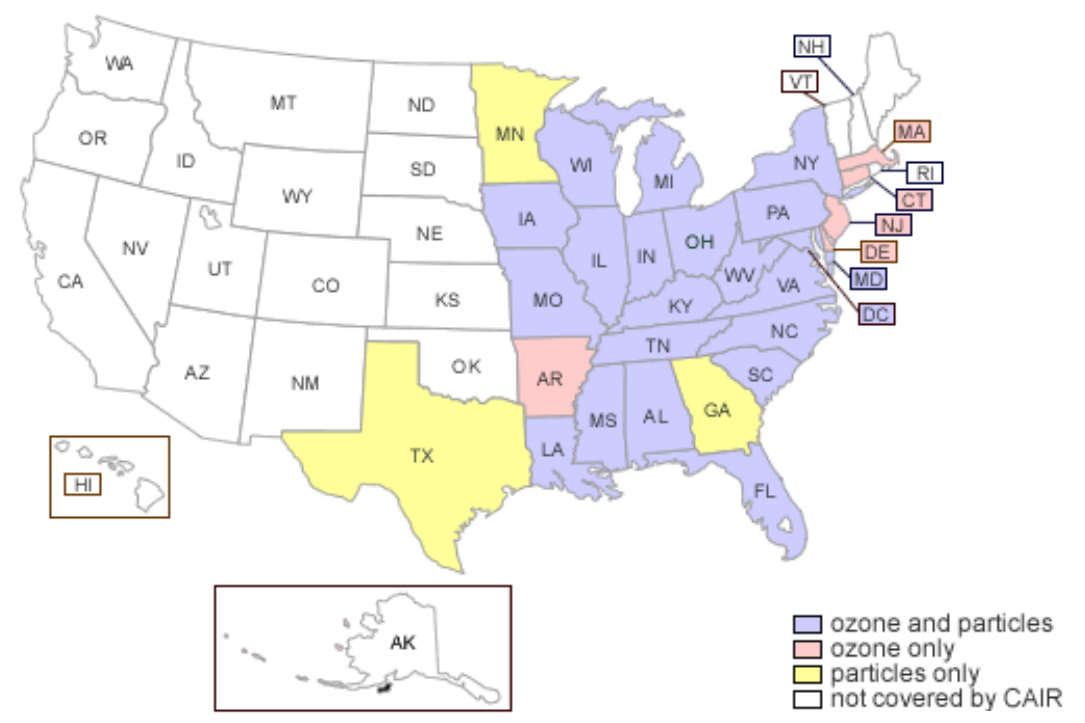

Figure 1. States affected by the Clean Air Interstate Rule (U.S. EPA)

Regulated states have the option of implementing the reductions through a regional trading program or through individual state emission reduction programs. If states choose to participate in the trading program, they must adopt a model rule issued by the U.S. EPA that lays out the basic structure of the program (70 FR 25162, 5/21/05). While most of the components of the model rule are fixed to ensure smooth administration of the trading program, states are free to determine the method of allocating $\mathrm{NO}_{\mathrm{x}}$ allowances to regulated entities. $\mathrm{SO}_{2}$ allowances continue to be allocated consistent with Title IV of the Clean Air Act Amendments of 1990, so states do not have discretion on their distribution, and renewable energy cannot receive them at this time.

The CAIR model rule does not include renewable energy in the program. However, the EPA does acknowledge the inclusion of renewable energy and energy efficiency as additional mechanisms to achieve the program's emission reduction goals. EPA has provided guidance on including renewable energy and other emission reduction mechanisms in cap and trade programs [24]. 
The state response to CAIR can include any of the methods for incorporating renewable energy sources discussed in this report. Model CAIR language for alternative allocation methods, including the methods discussed in this paper, is provided in the August 2005 State and Territorial Air Pollution Program Administrators and the Association of Local Air Pollution Control Officials (STAPPA/ALAPCO) document, Alternative $\mathrm{NO}_{x}$ Allowance Allocation Language for the Clean Air Interstate Rule [27]. This document simplifies the process of altering the model state rule under CAIR for states that wish to include renewable energy sources and provides the exact wording for multiple alternative allocation methods under the CAIR. This section provides background on the CAIR allocation approach and the options for including wind generators provided by the STAPPA/ALAPCO document.

\subsection{The EPA Model Rule}

The EPA model rule allocates allowances to existing sources on an input basis, and to new sources on a modified output basis. The allocation methodology for the annual $\mathrm{NO}_{\mathrm{x}}$ program is described in subpart EE section 96.142 of the model rule, and the allocation for the seasonal $\mathrm{NO}_{\mathrm{x}}$ program is described in subpart EEEE, section 96.342. The provisions of the two sections are essentially identical in construction, so the provisions of the sections are referred to jointly in this document (for example, as $96 . x 40$ where $\mathrm{x}$ can be 1 or 3 , meaning section 96.140 or 96.340 ).

Section 96.x40 establishes the size of the state trading budgets. Section 96.x41 establishes the overall timing of the allocation programs, with the initial allocation in 2006 for the first 6 years of the program (2009-2014) and annual allocations thereafter. It also establishes procedures in case a state does not submit allocation data to the EPA. Section 96.x42 is the $\mathrm{NO}_{\mathrm{x}}$ allocation methodology itself. Within section 96.x42:

- paragraph (a) describes how the heat input baseline is calculated for different types of units;

- paragraph (b) establishes the number of allowances to be allocated and describes the allocation calculation;

- paragraph (c) describes the new source set-aside; and

- paragraph (d) governs the redistribution of unused allowances from the new source setaside.

The model rule allocates allowances based on their historic (baseline) heat input. The first step in the allocation process is to calculate the baseline heat input for each unit. Each unit then receives allowances proportional to its share of the total baseline heat input in the state. The units are dealt with in two categories for the calculation of the baseline heat input:

1. For older units (those that commenced commercial operation prior to 2001), the EPA approach is a fuel-weighted, heat input-based allocation. The baseline heat input for each unit is the three highest years of weighted heat input from 2000-2004. The heat input is weighted by 1.0 for coal-fired units, 0.6 for oil-fired units and 0.4 for other affected units. The allowances are allocated based on the weighted heat input. 
2. For units that went online starting in 2001, the model allocation rule uses a modified output-based approach with credit for CHP. The baseline heat input for these is based on electric output converted to heat input. The converted heat input is the average of the unit's three highest years of gross electric output for the first 5 years of operation converted to heat input using a heat rate of 7,900 British Thermal Units per kilowatthour (Btu/kWh) for coal units and 6,675 Btu/kWh for other fuels. This converted heat input (not adjusted by fuel) is used to allocate allowances for the 2001 and later units from the same pool as the pre-2001 units.

Once the baseline heat input is calculated for all of the affected units, the allowances are allocated based on each unit's share of the total heat input. The allowances available for allocation to these units are the portion of the state electric generating unit (EGU) budget minus the new source set-aside.

The initial allocation is in 2006 for the years 2009-2014. For the allocation in 2009 and each allocation thereafter, the allowances are reallocated for the year 6 years later. However, each unit's baseline heat input, once established, does not change. Each unit's allocation will also be reduced slightly as new plants come into the system and receive a share of the available allowances.

There is a new source set-aside that provides allowances for new units until they have established their 5 years of baseline data. The set-aside for $\mathrm{NO}_{\mathrm{x}}$ is $5 \%$ per year for 2009 through 2014 and 3\% in 2015 and thereafter. ${ }^{\mathrm{w}}$ A new unit can request allowances equal to its actual emissions from the prior year. The allocation may need to be prorated to stay within the set-aside if it is oversubscribed. As new plants establish their 5 years of baseline data, they begin to get allowances in the regular reallocation. Since 5 years of data are required for the baseline and the initial allocation in 2006 covers 2009-2014, most units that begin commercial operation after January 1, 2001 will not have enough data for the initial allocation in 2006 and will not be able to receive allowances in the regular allocation process until 2015.

\subsection{Renewable Energy Set-Aside}

A renewable energy set-aside can be incorporated into the CAIR by defining eligible renewable energy sources in the initial section and adding a section that establishes both the amount of the set-aside and a method for allocation to renewable energy sources.

Development of state-specific definitions of which renewable energy sources and what size projects are eligible, including specific definition of each eligible renewable resource, can avoid potential confusion on which sources are eligible for the set-aside. As discussed in the earlier section on renewable energy set-asides, placing a limit on size of eligible generators will decrease the administrative burden for the regulating agency but will exclude small projects from the set-aside allowance pool. Aggregation of small projects opens the opportunity for such projects and can be accomplished by including an additional definition.

\footnotetext{
" The EPA model rule erroneously lists these dates as "2009-2013" and "2014 and thereafter" in Section 96.x42 (c)(1). These dates should be corrected to "2009-2014" and "2015 and thereafter," independent of other changes.
} 


\section{Definitions - Section 96.x02}

Renewable energy unit means an electric generator or renewable energy project, equal or greater than $10 \mathrm{MW^{x }}$, which began commercial operation after January 1, 2001 and is powered by wind, solar, ocean thermal, wave, geothermal, or hydroelectric energy. ${ }^{y}$

Renewable energy project means a group of renewable energy units that, in aggregate, equal at least $10 \mathrm{MW}$ of rated capacity.

The operation date of January 1, 2001 reflects the cutoff date for new sources in the CAIR. The renewable energy set-aside operation date can be altered to include existing renewable energy capacity or goals for renewable energy growth. If the date is set later, there is a larger portion of set-aside allowances for new renewable energy sources, creating a stronger incentive for development of new renewable energy sources. Conversely, a later date excludes existing renewable energy sources. Setting an operation date cutoff will require making tradeoffs between new and existing renewable energy generation.

Once eligible units are properly defined, the set-aside language must identify the size of the renewable energy set-aside, how renewable energy units apply for allowances, how allowances are distributed among applicants, and how undersubscribed or oversubscribed allowances are handled. The STAPPA/ALAPCO language is based on other set-aside language in the model rule. The size of the renewable set-aside is typically $3 \%$ to $5 \%$ of the total allowance pool [26]; however, individual states will need to adapt this to their expectations of renewable generation and other state-specific considerations. The STAPPA/ALAPCO language bases the allowance allocation on an output-based emission factor. This is a simple approach that can be related back to the allocation in the main program. If the renewable set-aside is oversubscribed, the allocations are prorated based on generation. Any unused allowances from the set-aside are reallocated to the main allowance pool. The specific set-aside language follows.

$N O_{X}$ Allowance Allocations $-\S 96 . x 42$

(d) For each control period in 2009 and thereafter, the permitting authority will allocate CAIR $\mathrm{NO}_{x}$ allowances to qualifying renewable energy units in the State, in accordance with the following procedures:

(1) The permitting authority will establish a separate renewable energy set-aside for each control period. Each new renewable set-aside will be allocated CAIR NO allowances equal to $5 \%$ of the amount of tons of $\mathrm{NO}_{x}$ emissions in the State trading budget under $\$ 96 . x 40$.

\footnotetext{
x The size cut-off was set lower than the main program's $25 \mathrm{MW}$ limit to include more projects.

${ }^{\mathrm{y}}$ The choice to include other renewable energy sources that emit $\mathrm{NO}_{\mathrm{x}}$ requires additional consideration and action by the state to properly define eligible units and evaluate the impact on overall emissions.
} 
(2) The CAIR designated representative of such a renewable energy unit may submit to the permitting authority a request, in a format specified by the permitting authority, to be allocated CAIR NO $\mathrm{N}_{x}$ allowances, starting with the later of the control period in 2009 or the first control period after the control period in which the energy efficiency or renewable unit commences commercial operation. The CAIR NO allowance allocation request must be submitted on or before July 1 of the first control period for which the CAIR NO $\mathrm{O}_{x}$ allowances are requested and after the date on which the renewable unit commences commercial operation.

(3) In a CAIR NO $O_{x}$ allowance allocation request under paragraph (d)(2) of this section, the CAIR-designated representative may request for a control period CAIR $N O_{x}$ allowances in an amount not exceeding:

(i) For a renewable energy unit, the control period gross electrical output of the facility during the calendar year immediately before such control period multiplied by 1.5 $\mathrm{lb} / \mathrm{MWh}$ for the years 2009-2014, or $1.25 \mathrm{lb} / \mathrm{MWh}$ for 2015and thereafter and divided by 2000 and rounded to nearest whole allowance as appropriate.

(4) The permitting authority will review each CAIR NO $O_{x}$ allowance allocation request under paragraph (d)(2) of this section and will allocate CAIR $N O_{x}$ allowances for each control period pursuant to such request as follows:

(i) The permitting authority will accept an allowance allocation request only if the request meets, or is adjusted by the permitting authority as necessary to meet, the requirements of paragraphs (d)(2) and (3) of this section.

(ii) On or after July 1 of the control period, the permitting authority will determine the sum of the CAIR NO $\mathrm{O}_{x}$ allowances requested (as adjusted under paragraph (d)(4)(i) of this section) in all allowance allocation requests accepted under paragraph (d)(4)(i) of this section for the control period.

(iii) If the amount of CAIR NO allowances in the renewable set-aside for the control period is greater than or equal to the sum under paragraph (d)(4)(ii) of this section, then the permitting authority will allocate the amount of CAIR NO $O_{x}$ allowances requested (as adjusted under paragraph (d)(4)(i) of this section) to each CAIR NO ${ }_{x}$ unit covered by an allowance allocation request accepted under paragraph (d)(4)(i) of this section.

(iv) If the amount of CAIR NO allowances in the new unit set-aside for the control period is less than the sum under paragraph (d)(4)(ii) of this section, then the permitting authority will allocate to each CAIR NO $O_{x}$ unit covered by an allowance allocation request accepted under paragraph (d)(4)(i) of this section the amount of the CAIR NO $\mathrm{O}_{x}$ allowances requested (as adjusted under paragraph (d)(4)(i) of this section), multiplied by the amount of CAIR NO allowances in the new unit set-aside for the control period, divided by the sum determined under paragraph (d)(4)(ii) of this section, and rounded to the nearest whole allowance as appropriate. 
(v) The permitting authority will notify each CAIR-designated representative that submitted an allowance allocation request of the amount of CAIR $N O_{x}$ allowances (if any) allocated for the control period to the renewable unit covered by the request.

Finally, the set-aside must be deducted from the main allowance pool for existing conventional units. In the CAIR model rule, the main allowance pool is $95 \%$ of total allowances from 2009 until 2014, and $97 \%$ thereafter. This reflects the suggested set-aside for new sources of 5\% and $3 \%$ respectively. Once a renewable energy set-aside amount is determined, the main allowance pool percents should be adjusted accordingly.

NO $O_{X}$ Allowance Allocations $-\S 96 . x 42$

(b)(1) For each control period in 2009 and thereafter, the permitting authority will allocate to all CAIR $N O_{x}$ units in the State that have a baseline heat input (as determined under paragraph (a) of this section) a total amount of CAIR NO $x$ allowances equal to 95\% for a control period during 2009 through 2014, and 97\% for a control period during 2015 and thereafter, of the tons of $N O_{x}$ emissions in the State trading budget under $\$ 96 . x 40$ (except as provided in paragraph (d) of this section).

\subsection{Direct Allocation to Renewable Energy}

While renewable energy set-asides have been used in the past, existing emission reduction cap and trade programs to date have not included an output-based allocation to renewable generators. However, the CAIR model rule already allocates allowances for new sources based on output, so it is easy to allocate allowances to new sources of renewable energy on an output basis. This can be accomplished by re-defining units eligible for new source allocations to include renewable energy sources. Once included in the definition, renewable sources can be allocated allowances from the main allowance pool at the same rate as other new units, where renewable energy generation output is multiplied by $6,675 \mathrm{Btu} / \mathrm{kWh}$, the rate used for other fuels besides coal. An eligible unit for new source allocations can be defined as:

\section{Definitions - Section $96 . x 02$}

Covered unit means a CAIR NOx unit, or a non-emitting electric generator or project with a nameplate capacity greater than [25 MW] that began commercial operation after January 1, 2001 and is powered by [wind, solar, ocean thermal, wave, geothermal, or hydroelectric energy].

The eligibility of various renewable energy technologies and capacity size would be determined by each state depending on its market for renewable energy sources. Non-polluting renewable energy sources provide the greatest emission reductions. This revised definition is then used as the basis for allocating allowances under Section 96.x42:

(A)(1)(ii) For [covered units] commencing operation on or after January 1, 2001: 


\subsubsection{Full Output-Based Allocation System}

While the existing CAIR model rule is a hybrid of heat input and output-based allocation systems, allocating the entire allowance pool under the CAIR based on generation output provides the strongest and most stable incentive for investment in clean, renewable energy and efficient conventional generators. A full output-based allocation would allow both existing and new renewable energy sources to receive allowances and realize their value through the market or through emission reduction claims. A full output-based system can be adopted under the CAIR by replacing the separate allocation for new and old units with one, consistent outputbased allocation approach for all units.

$\S 96 . x 42$ CAIR NO allowance allocations.

(a)(1) The baseline generation (in MWh) used with respect to CAIR $N O_{x}$ allowance allocations under paragraph (b) of this section will be:

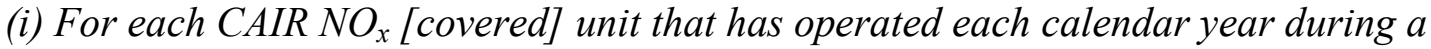
period of 5 or more consecutive calendar years, the average of the 3 highest amounts of the unit's control period gross electrical output over the 5 years prior to the allocation year, provided that if a generator is served by 2 or more units, then the gross electrical output of the generator will be attributed to each unit in proportion to the unit's share of the total control period heat input of such units for the year;...

The definition of "covered" unit would be as discussed above.

\subsubsection{New Source Set-Aside}

The previous changes account for allocation to new sources, renewable and conventional, once they are eligible for allocations from the main allowance pool. However, new sources must establish a 5-year data baseline before they are eligible for allocation. Once the baseline is established, allowances are allocated for the year 6 years following the allocation. Thus there is a lag of approximately 12 years between the start-up of a new facility and the point at which it receives allowances under the primary allocation program. Under the current CAIR model rule, new sources are allocated allowances from a new source set-aside until they establish their baseline and start to receive regular allocations.

The model rule suggests a new source set-aside equal to $5 \%$ of the total allowance pool from 2009-2014, and 3\% thereafter. While receiving allowances from this set-aside, conventional generators can apply for allowances not greater than their emissions for the previous year. The set-aside allocation is designed to make conventional generators "whole" until they are able to receive allowances from the main allowance pool and does not require a reduction in emissions.

If renewable generators receive allocations from a renewable energy set-aside, they can apply for those allowances as soon as they start to operate. If they are receiving allocations through a direct output-based allocation, however, they will be subject to the same 12-year lag as conventional generators and so would also need to be included in the new sources set-aside to receive any benefit during that time. 
Non-emitting renewable energy generators cannot apply for allowances based on historic emissions, so the allocation can be based on a standard allocation factor until the new renewable energy sources meet the baseline period for direct allowance allocation from the main allowance pool.

The required change is to modify the new source set-aside as follows:

Section 96.x42

(c)(2) The CAIR-designated representative of such a covered unit may submit to the permitting authority a request, in a format specified by the permitting authority, to be allocated CAIR NO $\mathrm{N}_{x}$ allowances, starting with the later of the control period in 2009 or the first control period after the control period in which the CAIR NO unit commences commercial operation and until the first control period for which the unit is allocated CAIR NO $\mathrm{N}_{x}$ allowances under paragraph (b) of this section. The CAIR NO $\mathrm{x}_{x}$ allowance allocation request must be submitted on or before July 1 of the first control period for which the CAIR NO $\mathrm{O}_{x}$ allowances are requested and after the date on which the CAIR $N O_{x}$ unit commences commercial operation.

(3) In a CAIR NO allowance allocation request under paragraph (c)(2) of this section, the CAIR-designated representative may request for a control period CAIR NO allowances in an amount not exceeding:

(i) for CAIR NO $\mathrm{O}_{x}$ unit, the total tons of $\mathrm{NO}_{x}$ emissions during the calendar year immediately before such control period.

(ii) for a covered renewable generator, the control period gross electrical output of the facility during the calendar year immediately before such control period multiplied by $1.5 \mathrm{lb} / \mathrm{MWh}$ for the years 2009-2014, or $1.25 \mathrm{lb} / \mathrm{MWh}$ for 2015 and thereafter and divided by 2000 and rounded to nearest whole allowance as appropriate.

Even though the suggested set-aside is $5 \%$, states can alter this amount to accurately reflect the expected growth of generation in their state. Inclusion of renewable generators in the new source set-aside may require states to increase the size of the set-aside.

\subsection{Decrease Lag Time for Allocations}

As noted above, there is an extensive lag time between receiving allocations from the new source set-aside and receiving allocations from the main allowance pool under the proposed allocation schedule for the EPA model CAIR. This time lag decreases the value of the allowance allocation to new conventional and renewable energy generators because of the potential that the new source set-aside would not be large enough to cover all applicants. This provides less incentive for new wind development. There are various methods to decrease the lag time in the CAIR, which would incorporate new sources into the main allowance pool more quickly and provide greater certainty of the allowance value to new non-emitting renewable energy sources. One method is to shorten the baseline period of generation for new sources from the suggested 5 years to 3 years. This can be accomplished by adding the following section: 
Section 96.x42

(a)(1)(ii)(A) For units operating each calendar year during a period of at least 3 but less than 5 consecutive calendar years, the average of the 3 highest amounts of the unit's total converted control period heat input over the consecutive years of operation.

This will allow existing units in operation after January 1, 2001, as well as units that commence operation after the initial allocation, to move into the main allowance pool more quickly. The allocation period and the lag between allocation and allowance use can also be shortened (e.g., allocate allowances for the year 3 years after the allocation period rather than 6 years after). Appropriate wording for a shortened lag time can be found in the STAPPA/ALAPCO document [27]. 


\section{Summary and Conclusions}

Cap and trade programs are one of the leading policy choices to reduce emissions from electricity generation in the United States. Cap and trade programs use market-based trading of emission allowances to minimize compliance cost and provide flexibility to affected entities.

Citing expected environmental and economic benefits, some programs include renewable generation. However, to date these programs have had little participation of renewable generators, including wind generation. As a non-emitting, increasingly competitive technology with growing generation capacity, wind is of particular interest because of its eligibility regardless of emissions or vintage restrictions of some programs, and the potential that the cap and trade incentive could make a difference in capacity expansion.

If policymakers include renewable energy in cap and trade programs, there are several mechanisms by which wind generators can gain value from participating in the program:

- If they receive an allocation of emission allowances and then sell them to emitting generators;

- If they receive allowances and use them to enhance their participation in voluntary retail renewable energy markets; or

- If they use them to make creditable emission reduction claims.

- If the program design distributes allowances by auction instead of by free allocation, policymakers would need to decide how to spend auction proceeds and could choose to use them to benefit wind generators among others.

Renewable generators, such as wind generation, can be incorporated in generation-based cap and trade programs in a manner that provides the strongest incentive, with minimal additional complexity, to achieve greatest overall benefits. There are two methods of accomplishing allocation of allowances to wind generators that are now in use or under consideration:

- A renewable energy set-aside establishes a pool of allowances that can be allocated to wind generators, usually based on their generation output. Renewable set-asides have been established in several emission trading programs to date. They provide certainty to market participants on the amount of allowances that will be available for renewable generators. Two primary drawbacks of this approach reduce its effectiveness and its financial value as an incentive for wind project development: the set-aside may be too small to provide consistent value to all new wind generators in the long term, and the administrative costs for regulators and affected generators may exceed desired levels.

- Direct output-based allocation to renewable generators allocates allowances to wind generators from the main allowance pool based on their generation output. This makes the generators part of the main allocation process and avoids additional administrative costs for regulators and affected entities. It also avoids the establishment of a fixed limit on allocations to wind generators. Drawbacks to this approach are that it has not been applied 
in emission trading programs to date and that it faces greater political opposition than setasides because it could reduce the number of allowances that will be allocated to existing conventional generators in the long term.

Sample regulatory language to allocate allowances to wind generators is straightforward and available. The CAIR represents the most immediate opportunity to apply this approach. Future trading programs, especially for $\mathrm{CO}_{2}$, may present similar opportunities.

Experience to date suggests that participation of wind generators in cap and trade program is highly sensitive to transaction costs and regulatory issues. Continued evaluation of "best practices" for incorporating wind generation can improve design and implementation of these programs to increase their benefits. 


\section{Appendix A. Resources}

\section{Cap and Trade Programs}

\section{Acid Rain Program:}

Ellerman, A.D.; Schmalensee, R.; Joskow, P.L.; Montero, J.P.; Bailey, E.M. "Emission Trading Under the U.S. Acid Rain Program: Evaluation of Compliance Costs and Allowance Market Performance." Center for Energy and Environmental Policy Research. Massachusetts Institute of Technology. http://web.mit.edu/ceepr/www/napap.pdf

Ellerman, A.D. "Lessons from Phase 2 Compliance with the U.S. Acid Rain Program." Center for Energy and Environmental Policy Research, Massachusetts Institute of Technology, May 2003. http://web.mit.edu/ceepr/www/2003-009.pdf

U.S. Environmental Protection Agency. "Acid Rain Program, 2004 Progress Report." Office of Air and Radiation, April 2004. http:/www.epa.gov/airmarkets/cmprpt/arp04/2004report.pdf

\section{NO $_{\mathrm{X}}$ Budget Program:}

\section{Output-Based Allocation}

Fischer, C.; Fox, A. (December 2004). "Output-Based Allocations of Emission Permits." Washington, DC: Resources for the Future. http://www.rff.org/Documents/RFF-DP-04-37.pdf

ERG; Energy and Environmental Analysis, Inc. "Output-Based Regulations: A Handbook for Air Regulators.” http://www.epa.gov/chp/pdf/OBR_final_9-1-05.pdf

U.S. EPA. "Developing and Updating Output-Based $\mathrm{NO}_{\mathrm{x}}$ Allowance Allocations." May 8, 2000. http://www.epa.gov/airmarkets/fednox/april00/finaloutputguidanc.pdf

Energy and Environmental Analysis, Inc. "Analysis of Output-Based Allocation of Emission Trading Allowances.” http://uschpa.admgt.com/AllocationFinal.pdf

\section{Alternative Allocations for Renewable Energy}

Wooley, D.R.; Morrs, E.M. (December 2000). "The Clean Air Act Amendments of 1990: Opportunities for Promoting Renewable Energy.” NREL/SR-500-29448. Golden, CO: National Renewable Energy Laboratory. http://www.nrel.gov/docs/fy01osti/29448.pdf

State and Territorial Air Pollution Program Administrators and the Association of Local Air Pollution Control Officials. "Alternative NOx Allowance Allocation Language for the Clean Air Interstate Rule.” http://www.4cleanair.org/Bluestein-cairallocation-final.pdf. August 2005. pp. 14-16.

"Improving Regional Air Quality with Wind Energy." (May 2005.) National Renewable Energy Laboratory. http://www.nrel.gov/docs/fy05osti/38071.pdf 


\section{Greenhouse Gases:}

Burtraw, D.; Palmer, K.L.; Kahn, D.B. (May 2005). “Allocation of $\mathrm{CO}_{2}$ Emissions Allowances in the Regional Greenhouse Gas Cap-and-Trade Program." Resources for the Future.

\section{Wind Energy}

\section{Wind Energy Overview:}

Reeves, A. (July 2003). "Wind Energy for Electric Power: A REPP Issue Brief." Washington, DC: Renewable Energy Policy Project. http://www.repp.org/articles/static/1/binaries/wind\%20issue $\% 20$ brief FINAL.pdf

\section{Economic Impact:}

Wind Economic Development. U.S. DOE/NREL Wind Powering America Program. http://www.eere.energy.gov/windandhydro/windpoweringamerica/economics.asp

Northwest Economic Associates for the National Wind Coordinating Committee. "Assessing the Economic Development Impacts of Wind Power." February 2003. http://www.nationalwind.org/publications/economic/econ_final_report.pdf

Pedden, M. "Analysis: Economic Impacts of Wind Applications in Rural Communities." NREL/SR-500-39099. Golden, CO: National Renewable Energy Laboratory, January 2006. http://www.nrel.gov/docs/fy06osti/39099.pdf

\section{Job Growth:}

Regional Economic Application Laboratory for the Environmental and Law Policy Center. "Job Jolt: The Economic Impacts of Repowering the Midwest.” 2001. http://www.repowermidwest.org/Job\%20Jolt/JJfinal.pdf

\section{Hedge against Fuel Volatility and Cost Savings from Wind Energy:}

Piwko, R.; Bai, X.; Clark, K.; Jordan, G.; Miller, N.; Zimberlin, J. 2005. The Effects Of Integrating Wind Power On Transmission System Planning, Reliability, And Operations, Report On Phase 2: System Performance Evaluation. Prepared for the New York State Energy Research and Development Authority (NYSERDA), Albany, NY. Prepared by GE Energy, Energy Consulting, March 4 (See section 2.3.6). http://www.nyserda.org/publications/wind integration_report.pdf

Wiser, R.; Bolinger, M.; St. Clair, M. "Easing the Natural Gas Crisis: Reducing Natural Gas Prices through Increased Deployment of Renewable Energy and Energy Efficiency." Berkeley, CA: Lawrence Berkeley National Laboratory, 2005. http://wwwlibrary.lbl.gov/docs/LBNL/567/56/PDF/LBNL-56756.pdf

\section{Energy and Environment:}

U.S. Environmental Protection Agency. (April 2006.) "The Clean Energy-Environment Guide to Action." http://www.epa.gov/cleanenergy/pdf/gta/guide action full.pdf 


\section{Appendix B. Resolution Supporting Emissions Allocations for New Clean Energy Sources}

WHEREAS, Encouraging cost-effective use of renewable energy resources has been an important national goal under past utility regulatory policy, including the Public Utility Regulatory Policies Act of 1978 and the Energy Policy Act of 1992; and

WHEREAS, Renewable energy supply brings fuel diversity benefits and mitigates fuel market power in the nation's mix of energy supplies, and enhances national security, reduces dependence on imported fuels, and decreases environmental impacts; and WHEREAS, "NARUC's National Electricity Policy," adopted November 13, 2001, supports addressing all air emissions from all electric power generation in ways that: 1) minimize adverse environmental impacts; 2) are comprehensive and synchronized to reduce regulatory costs; 3 ) rely, to the extent possible, on market-based trading mechanisms, and 4) identify, to the extent possible, the net impact of resource decisions, including external factors, on public health, the environment and the economy; and WHEREAS, Renewable energy sources and efficient cogeneration facilities typically generate power with reduced air emissions, if any, compared to conventional power plants; and

WHEREAS, The U.S. Environmental Protection Agency has proposed its "Clean Air Interstate Rule" (CAIR) which would, among other things, impose new emissions caps on power generating units and reserve for States the authority to allocate $\mathrm{NO}_{\mathrm{x}}$ emissions allowances within each State; and

WHEREAS, Cap and trade programs traditionally do not allow a generator utilizing renewable energy to receive an emissions allowance allocation on the same basis as an equivalent fossil-fired generator; and

WHEREAS, The exclusion of non-fossil generators from emissions allocations for new facilities places renewable energy sources at a disadvantage compared to fossil-fired resources and thereby perpetuates our nation's reliance upon finite fossil fuel resources; and

WHEREAS, Under existing cap and trade programs, a generator utilizing efficient cogeneration technology receives no more emissions allowances than a conventional generator despite its superior efficiency; and

WHEREAS, Under EPA's new CAIR proposal, $\mathrm{NO}_{\mathrm{x}}$ allowances would be allocated to new generating sources based on output; now therefore be it

RESOLVED, That the Board of Directors of the National Association of Regulatory Utility Commissioners (NARUC), convened in its 2004 Summer Meetings in Salt Lake City, Utah, urges Federal and State environmental authorities, in designing and implementing emissions cap and trade programs, to allocate emissions allowances in a manner that rewards efficient performance in new power generating facilities as EPA's CAIR rule proposes; and be it further

RESOLVED, That the NARUC further urges Federal and State environmental authorities to allocate emissions allowances equally to all new fossil and non-fossil generators, including renewables, according to their output.

Sponsored by the Committee on Energy Resources and the Environment Adopted by the NARUC Board of Directors July 14, 2004 


\section{Appendix C. $\mathrm{NO}_{x}$ Budget Trading Program Set-Aside Rationales}

Massachusetts Department of Environmental Protection:

...to encourage and reward the development of emission-reducing energy technologies in the Commonwealth. Many energy efficiency and renewable technologies have not matured to the point where they can compete with existing electricity generation units on the basis of price alone. However, these technologies can provide significant benefits by reducing impacts on human health, air, water, and land from electricity generation, reducing costs to the states to comply with federal environmental requirements, and generating in-state economic benefits associated with expenditures in local energy efficiency and renewable energy industries. ${ }^{\mathrm{z}}$

Indiana Department of Environmental Management:

IDEM believes that the inclusion of a set-aside specifically for EE/RE projects will provide several benefits. By providing EE/RE projects with allowances that can be sold into the $\mathrm{NO}_{\mathrm{x}}$ allowance trading system, the set-aside will help to improve air quality by providing incentives to produce energy using low or zeroemitting technologies and to prevent $\mathrm{NO}_{\mathrm{x}}$ emissions by increasing the efficiency of energy generation or use. Besides improving air quality, a set-aside that provides incentives for a variety of highly efficient or low emitting technologies will also diversify energy production in Indiana and provide greater system reliability. ${ }^{\text {aa }}$

New York State Energy Plan:

The Set-Aside Program recognizes that emission reductions needed to meet air quality objectives can be achieved by implementing end-use electric energy efficiency measures and renewable energy projects as well as by installing control devices on fossil fuel-fired electricity generation sources. Ancillary environmental benefits of the program include year-round reductions of $\mathrm{NO}_{\mathrm{X}}$ emissions, thereby contributing to reducing acid deposition in the sensitive receptor areas of the Adirondacks, as well as reducing eutrophication (i.e., nutrient-loading) of water bodies such as the Long Island Sound. Furthermore, energy efficiency measures and renewable energy projects contribute to reducing emissions of carbon dioxide, the primary greenhouse gas, thereby providing long-term climate change benefits. $^{\text {bb }}$

Elsewhere, the New York State Energy Research and Development Authority has studied the effects of renewable electricity generation and noted potential economic benefits. ${ }^{\text {cc }}$

\footnotetext{
${ }^{\mathrm{z}}$ http://www.mass.gov/dep/air/community/728rtc.pdf. SUMMARY OF COMMENTS AND RESPONSE TO COMMENTS FROM PUBLIC HEARINGS ON PROPOSED REVISIONS TO THE STATE IMPLEMENTATION PLAN FOR OZONE, INCLUDING PROPOSED 310 CMR 7.28 Held: Monday, August 3, 1999 in Springfield, Massachusetts Tuesday, August 4, 1999 in Boston, Massachusetts Thursday, October 28, 1999 in Boston, MA.

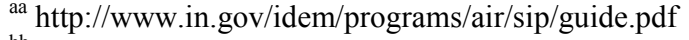

${ }^{\mathrm{bb}} \mathrm{http} / / /$ www.nyserda.org/Energy Information/energy state plan.asp

http://www.nyserda.org/sep/sepsection2-3.pdf, June 2002, The 2002 State Energy Plan and Final Environmental Impact

Statement (Energy Plan)

${ }^{\mathrm{cc}}$ http://www.nyserda.org/sep/EE\&ERpotentialVolume1.pdf
} 


\section{Glossary of Abbreviations and Acronyms}

$\begin{array}{ll}\text { Btu } & \text { British Thermal Unit } \\ \text { CAIR } & \text { Clean Air Interstate Rule } \\ \mathrm{CHP} & \text { combined heat and power } \\ \mathrm{CO}_{2} & \text { carbon dioxide } \\ \mathrm{EE} / \mathrm{RE} & \text { Energy Efficiency and Renewable Energy } \\ \mathrm{EGU} & \text { Electric Generating Unit } \\ \mathrm{GHG} & \text { greenhouse gas } \\ \mathrm{kW} & \text { kilowatt } \\ \mathrm{kWh} & \text { kilowatt-hour } \\ \mathrm{lbs} & \text { pounds } \\ \mathrm{MW} & \text { megawatt } \\ \mathrm{MWh} & \text { megawatt-hour } \\ \mathrm{NO} & \text { nitrogen oxides } \\ \mathrm{PM} & \text { particulate matter } \\ \mathrm{REC} & \text { Renewable Energy Certificate } \\ \mathrm{RGGI} & \text { Regional Greenhouse Gas Initiative } \\ \mathrm{RPS}_{\mathrm{SIP}} & \text { Renewable Portfolio Standard } \\ \mathrm{SO}_{2} & \text { State Implementation Plan } \\ \end{array}$




\section{References}

1. U.S. EPA, Office of Air and Radiation, Tools of the Trade: A Guide to Designing and Operation a Cap and Trade Program for Pollution Control, EPA 430-B-03-002, June 2003.

http://www.epa.gov/airmarkets/international/tools.pdf

2. U.S. EPA. Cap and Trade: Essentials. http://www.epa.gov/airmarkets/capandtrade/ctessentials.pdf. Accessed June 14, 2006.

3. U.S. EPA. Office of Air and Radiation. Clean Air Act Overview. http://www.epa.gov/oar/caa/overview.txt Accessed April 27, 2006.

4. U.S. EPA Clean Air Markets. Programs and Regulations. $N O_{X}$ Trading Programs. Overview of NOx Trading Program. http://www.epa.gov/airmarkets/progsregs/noxview.html. Accessed June 14, 2006.

5. U.S. EPA Clean Air Markets. Programs and Regulations. $N_{x}$ Budget Trading Program. www.epa.gov/airmarkets/fednox/index.html. Accessed April 27, 2006.

6. U.S. EPA Office of Air and Radiation. Clean Air Interstate Rule http://www.epa.gov/airmarkets/cair/index.html. Accessed April 27, 2006.

7. Regional Greenhouse Gas Initiative. www.rggi.org/. Accessed April 27, 2006.

8. U.S. EPA Clean Air Markets. Multi-Pollutant Analyses. www.epa.gov/airmarkets/mp/. Accessed April 27, 2006.

9. USCHPA, 2003. This section adapted from Analysis of Output-Based Allocation of Emission Trading Allowances, http://uschpa.admgt.com/AllocationFinal.pdf.

10. Ellerman, D., P. Joskow, and D. Harrison Jr. Emissions Trading in the U.S.: Experience, Lessons and Considerations for Greenhouse Gases. Prepared for the Pew Center on Global Climate Change by Massachusetts Institute of Technology and the National Economic Research Associates, Inc. May 2003.

11. Fischer, C. and A. Fox. Output-Based Allocations of Emission Permits. December 2004. Resources for the Future. RF DP 04-37. www.rff.org/Documents/RFF-DP-04-37.pdf

12. Tools of the Trade: A Guide to Designing and Operation a Cap and Trade Program for Pollution Control. U.S. EPA, Office of Air and Radiation, EPA 430-B-03-002, June 2003. http://www.epa.gov/airmarkets/international/tools.pdf

13. Regional Greenhouse Gas Initiative. Staff Working Group Model Rule. March 23, 2006 http://www.rggi.org/docs/public_review_draft_mr.pdf. p.40. Accessed April 27, 2006. 
14. U.S. EPA. The Clean Energy-Environment Guide to Action, February 2006. p. 409. http://www.epa.gov/cleanenergy/stateandlocal/guidetoaction.htm

15. NYSERDA.Energy Efficiency and Renewable Energy Resource Development Potential in New York State. Final Report. Volume One: Summary Report. Prepared for New York State Energy Research and Development Authority (NYSERDA). Prepared by Optimal Energy, Inc. Bristol, Vt. August 2003. http://www.nyserda.org/sep/EE\&ERpotentialVolume1.pdf

16. Presentation by Bob McCarron and Jean Fenske, MPCA's Implementation of the Clean Air Interstate Rule, Minnesota Pollution Control Agency, June 20, 2006.

17. U.S. EPA. Regulatory Impact Analysis for the Final Clean Air Interstate Rule. March 2005. www.epa.gov/cair/technical.html.

18. Evolutions Market, LLC. Emission Markets. SIP $\mathrm{NO}_{\mathrm{x}}$ Market Data and Reports. www.evomarkets.com/. Accessed April 19, 2006.

19. DSIRE. Database of State Incentives for Renewable Energy. http://www.dsireusa.org

20. U.S. EPA. Office of Air and Radiation. Guidance on SIP Credits for Emission Reductions from Electric-Sector Energy Efficiency and Renewable Energy Measures. August 2004. www.epa.gov/ttn/oarpg/t1/memoranda/ereseerem_gd.pdf

21. Hathaway, A.; Jacobson, D.; High, C. Model State Implementation Plan Documentation for Wind Energy Purchase in State with Renewable Energy Set-Aside. NREL/SR-500-38075. Golden, CO: National Renewable Energy Laboratory, May 2005.

www.eere.energy.gov/windandhydro/windpoweringamerica/pdfs/wpa/sips_model.pdf

22. 42 U.S.C. 7651, Section 404. United States Code, Title 42: The Public Health and Welfare. Chapter 85, Air Pollution Prevention and Control. Subchapter IV-A, Acid Deposition Control. Section 7651, Findings and Purposes.

23. U.S. EPA (October 27, 1998). Finding of Significant Contribution and Rulemaking for Certain States in the Ozone Transport Assessment Group Region for Purposes of Reducing Regional Transport of Ozone; Rule (63 FR 57356), Washington, D.C.

24. U.S. EPA (March 1999 and April 2000). "Guidance on Establishing an Energy Efficiency and Renewable Energy (EE/RE) Set-Aside in the $\mathrm{NO}_{\mathrm{x}}$ Budget Trading Program." Volumes 1 and 2. http://www.epa.gov/cleanenergy/stateandlocal/guidance.htm, accessed March 1, 2006; last updated February 13, 2006.

25. Wooley, D.; Morss, E. The Clean Air Act Amendments of 1990: Opportunities for Promoting Renewable Energy. NREL/SR-620-29448. Golden, CO: National Renewable Energy Laboratory, 2001. 
26. U.S. EPA. "State Set-Aside Programs for Energy Efficiency and Renewable Energy Projects Under the NOx Budget Trading Program: A Review of Programs in Indiana, Maryland, Massachusetts, Missouri, New Jersey, New York, and Ohio.” EPA 430-R-03-005.

http://www.epa.gov/cleanenergy/stateandlocal/guidance.htm. Last modified February 13, 2006; accessed March 1, 2006.

27. State and Territorial Air Pollution Program Administrators and the Association of Local Air Pollution Control Officials. Alternative NOx Allowance Allocation Language for the Clean Air Interstate Rule. http://www.4cleanair.org/Bluestein-cairallocation-final.pdf August 2005. pp. 1416. 


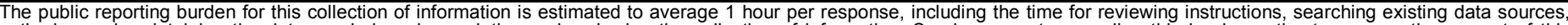

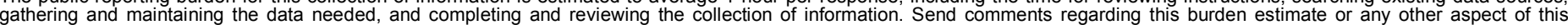

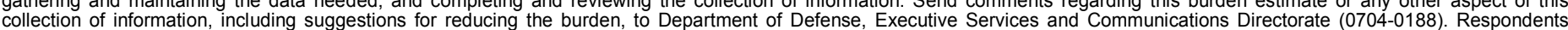

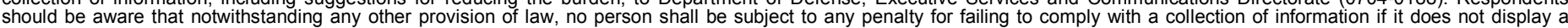

surrently valid OMB control number.

PLEASE DO NOT RETURN YOUR FORM TO THE ABOVE ORGANIZATION.

\begin{tabular}{l|l|l|l} 
1. REPORT DATE $(D D-M M-Y Y Y Y)$ & 2. REPORT TYPE & 3. DATES COVERED (FrOm - TO)
\end{tabular}

July 2006

Technical Report

4. TITLE AND SUBTITLE
Incorporating Wind Generation in Cap and Trade Programs

5a. CONTRACT NUMBER

DE-AC36-99-G010337

5b. GRANT NUMBER

5c. PROGRAM ELEMENT NUMBER

6. AUTHOR(S)

J. Bluestein, E. Salerno, L. Bird, and L. Vimmerstedt

5d. PROJECT NUMBER

NREL/TP-500-40006

5e. TASK NUMBER

WER6.6006

5f. WORK UNIT NUMBER
7. PERFORMING ORGANIZATION NAME(S) AND ADDRESS(ES)

National Renewable Energy Laboratory

1617 Cole Blvd.

Golden, CO 80401-3393

9. SPONSORING/MONITORING AGENCY NAME(S) AND ADDRESS(ES)
8. PERFORMING ORGANIZATION REPORT NUMBER

NREL/TP-500-40006

10. SPONSOR/MONITOR'S ACRONYM(S) NREL

11. SPONSORING/MONITORING AGENCY REPORT NUMBER

\section{DISTRIBUTION AVAILABILITY STATEMENT}

National Technical Information Service

U.S. Department of Commerce

5285 Port Royal Road

Springfield, VA 22161

\section{SUPPLEMENTARY NOTES}

\section{ABSTRACT (Maximum 200 Words)}

Cap and trade programs are increasingly being used to reduce emissions from electricity generation in the United States. Cap and trade programs primarily target emitting generators, but programs have also included renewable generators, such as wind generators. States cite several reasons why they have considered the policy option of including renewable generators in cap and trade programs: to provide an incentive for lower-emitting generation, to achieve emissions reductions in non-capped pollutants, and to gain local economic benefits associated with renewable energy projects. The U.S. Environmental Protection Agency also notes these rationales for considering this policy alternative, and the National Association of Regulatory Commissioners (NARUC) passed a resolution supporting the inclusion of renewable energy in cap and trade programs. This report explores why states consider this policy option, what participation could mean for wind generators, and how wind generation can most effectively be included in state, federal, and regional cap and trade programs.

15. SUBJECT TERMS

wind energy; cap and trade program; emissions; state policy; renewable energy; renewable generators; policy; cap and trade; Environmental Protection Agency; Clean Air Interstate Rule; air emissions; air quality; electricity; electricity generation; utilities; emissions markets; carbon; NOx; emissions trading

\begin{tabular}{|c|c|c|c|c|}
\hline 16. SECURITY & CLASSIFICATI & N OF: & 17. LIMITATION & 18. NUMBER \\
\hline $\begin{array}{l}\text { a. REPORT } \\
\text { Unclassified }\end{array}$ & $\begin{array}{l}\text { b. ABSTRACT } \\
\text { Unclassified }\end{array}$ & $\begin{array}{l}\text { c. THIS PAGE } \\
\text { Unclassified }\end{array}$ & $\begin{array}{l}\text { OF ABSTRACT } \\
\text { UL }\end{array}$ & \\
\hline
\end{tabular}

19a. NAME OF RESPONSIBLE PERSON
19b. TELEPHONE NUMBER (Include area code)

